NBER WORKING PAPER SERIES

\title{
THE IMPACT OF SOCIAL NETWORKS ON LABOUR MARKET OUTCOMES: NEW EVIDENCE FROM CAPE BRETON
}

\author{
Adnan Q. Khan \\ Steven F. Lehrer \\ Working Paper 18786 \\ http://www.nber.org/papers/w18786 \\ NATIONAL BUREAU OF ECONOMIC RESEARCH \\ 1050 Massachusetts Avenue \\ Cambridge, MA 02138 \\ February 2013
}

We wish to thank Charlie Beach, Doug Tattrie and seminar participants at the Income, Inequality and Immigration: A JDI Conference Honouring Charles M. Beach for helpful comments and suggestions on earlier drafts. This paper was motivated by several of Beach's recent papers including Abbott and Beach $(2008,2011)$ that postulated that the development of labour market connections by new immigrants may be an underlying factor in the immigrants' increasing earnings profile since landing. Lehrer wishes to thank SSHRC for research support. We are also extremely gratefully to members of SRDC for answering numerous questions about the data used in this study. The usual caveat applies. The views expressed herein are those of the authors and do not necessarily reflect the views of the National Bureau of Economic Research.

NBER working papers are circulated for discussion and comment purposes. They have not been peerreviewed or been subject to the review by the NBER Board of Directors that accompanies official NBER publications.

(C) 2013 by Adnan Q. Khan and Steven F. Lehrer. All rights reserved. Short sections of text, not to exceed two paragraphs, may be quoted without explicit permission provided that full credit, including (C) notice, is given to the source. 
The Impact of Social Networks on Labour Market Outcomes: New Evidence from Cape Breton Adnan Q. Khan and Steven F. Lehrer

NBER Working Paper No. 18786

February 2013

JEL No. C93,J08,Z18

\begin{abstract}
$\underline{\text { ABSTRACT }}$
Debates centered on the role of social networks as a determinant of labour market outcomes have a long history in economics and sociology; however, determining causality remains a challenge. In this study we use information on random assignment to a unique intervention to identify the impact of changes in the size of alternative social network measures on subsequent employment at both the individual and community level. Our results indicate that being assigned to the treatment protocol significantly increased the size of social networks, particularly weak ties. Nevertheless, these increases did not translate into improved employment outcomes 18 months following study completion. We do not find any evidence of treatment effect heterogeneity based on the initial size of one's social network; but those whose strong ties increased at a higher rate during the experiment were significantly less likely to hold a job following the experiment. We find that many of these results also hold at the community level among those who did not directly participate in the intervention. In summary, our results suggest that policies can successfully influence the size of an individual's social network, but these increases have limited impacts on long run labour market outcomes with the notable exception of changes in the composition of individuals who hold jobs.
\end{abstract}

Adnan Q. Khan

London School of Economics

International Growth Centre

Houghton Street

London WC2A 2AE, UK

a.q.khan@1se.ac.uk

Steven F. Lehrer

School of Policy Studies

and Department of Economics

Queen's University

Kingston, ON K7L 3N6

CANADA

and NBER

lehrers@post.queensu.ca 


\section{Introduction}

The notion that social networks affect labour market outcomes has been speculated about in a variety of strands of academic literature, and as popularly expressed by the phrase: "it's not what you know but who you know!". An increasing number of job searchers are using online social network websites such as LinkedIn to help find employment. In response, a growing number of websites offer advice on tactics individuals should employ on social network websites to access desired employment opportunities. While the idea that social networks influence a host of labour market activities has a long history, ${ }^{1}$ few studies present direct evidence of causal relationships from social networks to employment.

While substantial theoretical developments have been made on modeling the effects of social networks on a multitude of individual outcomes (see Jackson (2010, 2008) for a comprehensive survey of the literature in economics), little empirical evidence from Canada exists on whether and how social networks affect a variety of labour market outcomes. Empirical analyses on the effects of social networks have been plagued by various conceptual and data problems. Many commonly used datasets lack information on the structure and composition of individuals' social networks. Analyses are further complicated by various endogeneity issues such as the reflection problem and selection bias. A reflection problem arises when individual and network members' outcomes are determined simultaneously, which inherently confounds the measure of network's influence. Selection

\footnotetext{
${ }^{1}$ For instance, Ioannides and Loury (2004) report that between 30 and $60 \%$ of jobs are found through informal social network contacts Bayer et al. (2008), and Topa (2001) present evidence of network-based job referrals and informational spillovers in the U.S. labour market. Research in this area dates back to the classic study by Granovetter (1973) who showed the importance of social ties, especially weak ties, in finding a job. Granovetter (1995) presents evidence that professional, managerial and technical workers were much more likely to find jobs through weak ties than through strong ones. More recently, Garg and Telang (2011) present evidence that there is a stronger asssociation between job search outcomes and the size of weak contacts in online social networks relative to the number of strong ties in these networks.
} 
bias leads to a correlated unobservables problem if people tend to associate with others based in part on some unobserved group characteristics they favor. In such a case, an observed positive association between an individual's outcome and those of their associated network members' may not be causal but rather due to some unknown factors that affect both social links and individual's own labour market outcomes. This issue of endogenous group membership plagues all studies using observational data.

Researchers typically attempt to overcome the selection bias problem in one of two ways. Several studies have exploited credible exogenous variations to identify the effects of social networks on labour market outcomes. For example, Laschever (2009) examined the subsequent employment outcome of members of military units formed via the U. S. World War I draft. Beaman (2012) exploits the reallocation of political refugees from the same country to a particular city, conditional on the refugees not having family members in the United States to recover estimates of specific form of network effects free of selection bias. This type of approach, however, remains a rarity: researchers most commonly use an instrumental variables estimator (see Case and Katz (1991) and Apinunmahakul and Devlin (2008), among others) to mitigate the correlation between unobservables and network variables. However, the statistical properties and economic validity of the instrumental variables chosen are debated. ${ }^{2}$

This paper presents some initial evidence on how changes in different dimensions of social networks influence labor market activities in a specific region in Canada. We make use of data from the Community Employment Innovation Project (CEIP), an innovative labour market field experiment recently conducted in Cape Breton, Canada. Rather than proving traditional services to assist in job placement such as counselling services, this study provided community based employment allowing participants to acquire new skills and work experience while also developing valuable work-related networks and "social

\footnotetext{
${ }^{2}$ Heckman (1997) considers the economic interpretation of instrumental variable estimators in general.
} 
capital" that could lead to greater long-term employment success. The experiment utilized randomization and because of its design, allows a source of exogenous variation in the size of participants' social networks, which can be used to identify the impacts of social networks on subsequent employment. ${ }^{3}$ Specifically, we explore, at the individual level, whether changes in the size of social networks resulting from being assigned to receive the CEIP intervention affected employment in the medium to long term.

In the final evaluation report completed by the agency that oversaw the CEIP study, Guyamarti et al. (2008a, pp. 7) concluded that "it was uncertain, however, whether CEIP could improve skills and networks and whether this would increase post-program employment in an economically depressed area". Our analyses directly address this question. Further, we categorize the composition of an individuals' social networks according to several alternative membership criteria. Categories range from those who could provide employment advice, to close friends and family members. These distinctions in social network composition will be used to address the ongoing debate over whether weak ties are more important than strong ties for obtaining employment. ${ }^{4}$ In addition to collecting data on program participants and controls, CEIP researchers collected data on nonparticipant

\footnotetext{
${ }^{3}$ There are several other studies (e.g. Angelucci and De Giorgi (2009), Duflo and Saez (2003), and Miguel and Kremer (2003), among others). that use randomized experiments to identify social interactions. Our goal is to use a non-experimental approach with experimental data to isloate the causal effect of changes in social networks that arise from the experiment.

${ }^{4}$ This debate began with Granovetter (1973), who referred to weak ties as a network of acquaintances who are less likely to be socially involved with one another. While there is no universally accepted definition of weak ties, in general these refer to peripheral friends and random contacts who are not close in social space. The strength of weak ties remains an open empirical question (e. g. see Tassier (2006)). Strong ties are established with people who reinforce one's beliefs and provide support required to endure life's challenges, including close friends and relatives. Strong ties may help individuals find employment because they facilitate more frequent contact with the individual, increasing the likelihood of knowing that an individual is looking for a job, and have a greater motivation to provide job information, than weak ties.
} 
individuals from CEIP study communities as well as individuals from comparable nonparticipating communities. This allows us to additionally explore how the distribution of social networks changed at the community level as a result of the CEIP intervention. We broadly examine whether these aggregate changes led to changes in employment levels and network structures across regions.

This paper is organized as follows. In the next section, we describe the Community Employment Innovation Project and the manner in which data was collected from both study participants and non-participants. In section 3 we introduce the model that guides our estimation. We demonstrate that random assignment to the program in combination with our econometric methodology allows us to gain consistent estimates of the impacts of changes in social networks on labor market activities. Our empirical results are presented and discussed in section 4 . We present strong evidence that, while being assigned to the program did lead to increases in the size of a variety of social network variables, these effects did not translate into improved employment outcomes. Further, we find that these results also hold at the community level among those who did not participate in the CEIP program. Taken together, these results suggest that, while policies can successfully influence the size of an individual's social network, particularly in terms of weak ties, these increases do not affect subsequent labour market outcomes; particularly for those who experienced larger gains in the size of their strong ties during the experiment. The concluding section summarizes our findings and discusses directions for future research.

\section{Data}

The data for this study comes from the Community Employment Innovation Project (CEIP) which was conceived by Human Resources and Social Development Canada (HRSDC) as a long-term research and demonstration project for testing an alternative form of income transfer payment in economically depressed areas through community involvement. 
This study was conducted in the Cape Breton Regional Municipality located in the Canadian province of Nova Scotia. The goal of the project was to improve the long-term well-being of workers in communities experiencing chronically high unemployment, while simultaneously contributing to the development of those communities themselves. The program was designed to influence long term outcomes by assisting participants to develop valuable work-related networks and "social capital" that could lead to subsequent long-term employment success. CEIP was managed by the Social Research and Demonstration Corporation (SRDC) and data collection was conducted by Statistics Canada. While SRDC designed an extensive individual impact study to examine the effect of CEIP on participants' employment, earnings, and their use of social benefits, ${ }^{5}$ to the best of our knowledge there has not been an examination of one of the key pathways that was hypothesized to underlie the causal mechanism.

The CEIP researchers collected a myriad of longitudinal data sets. In this paper, we draw upon two datasets described below. First, the individual impact study followed participants in the CEIP impact evaluation for 54 months. Those interested in participating in the study were required to complete an enrolment form consisting of an informed consent. Participants for the experimental study were randomly selected from among welfare and EI beneficiaries residing in the Cape Breton Regional Municipality. ${ }^{6}$ After providing informed consent, individuals completed a survey that captured baseline measures on in-

\footnotetext{
${ }^{5}$ See Gyarmati et al. (2006, 2007, 2008a) for a series of impact evaluations of the CEIP.

${ }^{6}$ The selection was made from two broad groups - those from the Employment Insurance (EI) pool and those from the Income Assistance (IA) pool. Selection criteria for the participants reflected the rules and regulations that govern these transfer programs. EI beneficiaries were randomly selected from a monthly derivative of the HRDC Benefits and Overpayments file which is used for administering EI claims and payments. Eligible IA recipients were selected from among IA recipients who expressed an interest in participating in the project after being notified by the Nova Scotia Department of Community Service about CEIP and their eligibility to participate in the project. Once selected, individuals were informed about the project.
} 
dividual and socioeconomic characteristics. The individuals were then randomly assigned into either the CEIP treatment or control group. Randomization was conducted by Statistics Canada on dedicated random assignment software application, and procedures were adopted to protect the integrity of the process ${ }^{7}$

Individuals assigned to the intervention were offered eligibility for 36 months of community work in return for foregoing their welfare payments. The participants were paid at close to the minimum wage for work on projects developed by local project sponsors and community groups in program communities. All labour costs (as well as some other resources) of those randomly assigned to the CEIP intervention were covered by HRSDC. Those assigned were free to work on non-CEIP projects, but were to lose their eligibility to participate in the program if they were to return to welfare as a major source of income. The typical participant worked on multiple projects in the social sector during the course of the project. Finally, it is important to note that, generally, those from the EI pool have greater links to the labour market, while those from the IA pool have weaker links to the labour market and greater levels of poverty. ${ }^{8}$ Participant selection and enrolment was carried out in the period from June 2001 to June 2002.

\footnotetext{
${ }^{7}$ The procedure adopted and the different checks applied are described in detail in Greenwood et al. (2003, p.121-123).

${ }^{8}$ We present summary statistics based on treatment assignment later in this section. While both participant samples mostly represented disadvantaged populations there is considerable variation along several dimensions: The Employment Insurance (EI) sample is more likely to be male, at 58 per cent, while 62 per cent of the Income Assistance (IA) sample is female; the EI sample is typically older, with an average age of 40, while the IA sample age was 35 at baseline; the EI sample had a higher educational attainment, with 69 per cent holding a high school diploma compared to 60 per cent of the IA sample; the household income for most EI sample members was under $\$ 30,000$ during the 12 months before enrolment, while the household income of most IA enrollers was less than $\$ 20,000$ with over half of the sample reporting income of less than $\$ 10,000$; the EI sample had a longer work history than IA sample members at baseline (they were, however, also more likely to be unemployed due to a layoff, contract termination, or because their employer moved or closed down).
} 
All individuals in the impact study were initially surveyed at baseline with follow-up surveys 18, 40 and 54 months after random assignment. ${ }^{9}$ This data provides information on basic demographics (e.g., age, gender, and marital status, education and training), employment (e.g. including industry and occupation classification, job duration, absences, pay rate, seasonal or non-seasonal, characteristics of employer, and unionization) and the sources of personal and household income. Most importantly, a rich set of social network measures described in detail below were also collected.

The second source of data is the community effects survey. For this survey, information was independently collected from samples drawn from the full population of the communities under investigation. More specifically, random digit dialing was used to contact residents of the six program communities and seven comparison communities were contacted. ${ }^{10}$ Comparison communities were based in either Cape Breton or mainland Nova Scotia and were selected on a high degree of similarity, measured by proximity score analysis, to program communities. ${ }^{11}$ It should be noted that a subset of the community survey sample included those that were involved with the project (CEIP) in some capacity. These individuals are crucial for our identification strategy because their involvement with the project provides a source of exogenous variation in their social networks. All

\footnotetext{
${ }^{9}$ Each survey was staggered over time since induction into the project lasted over many months. The 54 month survey was conducted at least 12 months after the program ended for all participants.

${ }^{10}$ The CEIP program communities include Dominion, Glace Bay, New Waterford, North Sydney, Sydney Mines and Whitney Pier. The selected (program) communities had to agree to participate in the project by means of a show of support by the majority of those attending public meetings held in each community. Their subsequent participation in the CEIP involved multiple steps that led to the hiring of project participants. Details of the process are given in Gyarmati et al. (2006, 2007, 2008a).

${ }^{11}$ The process involved the following steps: establishing a list of candidate communities; calculating pooled statistics for each of the descriptive community characteristics; calculating the squared Euclidean distance of the normalized Census characteristic variables from every other community; and selecting the comparison communities and community groupings with the shortest squared Euclidean distances (Gyarmati et al. 2008a: appendix B).
} 
individuals in the community effects study were surveyed at three points in time, all of which correspond to the timing of the follow-up surveys in the CEIP experimental study.

Summary statistics for the data from the individual impact study used in this paper are presented in Table 1. Each column refers to summary statistics based on treatment status and survey wave. Comparing the first and fifth column we can observe that randomization was indeed successful since the observed characteristics are balanced across groups. ${ }^{12}$ As expected, rapid expansion of employment among treatment group participants is evident in the summary statistics for wave 2 and some difference in the average number of several of the social network variables, particularly those reflecting weak ties are evident in the summary statistics for wave 3 . Also, on average, members of the sample have very low levels of education with fewer than $20 \%$ of the sample holding either a 2-year college or university degree.

Summary statistics for the data from the community study are presented in Table 2. Columns were created based on: 1 . whether a community took part in the CEIP (program communities) and 2. The wave of the survey from which the data was derived. Program communities received community projects, whereas comparison communities did not. We found no significant differences over various outcomes of interest between these groups of communities on non-project related potential instruments. We did, however, find significant differences between these communities on project-related potential instruments such as social network variables. These differences were especially pronounced in the wave 3 survey. In our study, we consider multiple measures of social networks including: i) the number of family and friends; ii) the bonding network, the number of persons who can provide support when the respondent is sick, or can serve as someone the respondent can talk to when feeling down; iii) the bridge network, proxied by the number of persons who can loan the respondent $\$ 500$; and iv) linking contacts, the number of contacts

\footnotetext{
${ }^{12}$ Formal evidence of this claim is presented in Guyamarti et al. (2008).
} 
with higher socioeconomic status. Weak ties can be proxied by link and bridge variables whereas strong ties can be proxied by the bond variable.

Most of the participants in the community survey were likely to have lived on Cape Breton for all of their life. In terms of the highest level of education achieved, 56 percent have completed high school, 9 percent have bachelor degrees, and 3 percent have some university education. Approximately 23 percent of participants have trade-vocational and apprenticeship diplomas. Participants' mean annual personal income is $\$ 24,000$ while participants' mean annual household income is $\$ 39,000$. About 40 percent of individuals have income levels below the Low-Income Cut-off (LICO) of Statistics Canada. In terms of income source, roughly 25 percent of individuals receive work pensions, while 24 percent receive Employment Insurance (EI) or Social Assistance (SA). About 36 percent individuals are union members on the jobs they held at the baseline survey, while about 11 percent individuals, though not covered by a union, have their wages covered by union contracts.

The table also shows that the mean number of family members and friends the respondent sees and talks to are 9.65 and 9.52 respectively. The mean age of the participants in the estimation sample is 48 years; roughly 42 percent are males and 57 percent are married or living with a partner. In terms of family status, about 32 percent are single, without children; 11 percent are single with children; and 57 percent are couples with or without children. The mean household size is 2.68. The mean number of bonding and bridging contacts are 24.2 and 4.53 respectively. About 30 percent of the respondents have linking contacts.

\section{Empirical Model}

In this study, our primary goal is to present reduced form evidence on whether or not changes in the size of different forms of social networks are more effective at increasing 
labour supply on the extensive margin. As we explain later in this section, our empirical strategy will allow us to recover consistent estimates of the impact of changes in the size of social networks and not the levels. Thus, throughout our analyses, we take the network at the start of the experiment as given, ${ }^{13}$ and estimate how changes in the size of one's social network that occurred during the experiment affected the likelihood an individual is employed 18 months after the experiment was completed.

Our selection of evaluating labour market outcomes 18 months after the experiment was completed is based strictly on convenience, since this corresponds to the point in time when the final survey was conducted. However, in this final survey CEIP researchers did ask respondents a series of retrospective questions on when a job began, as well as also collected six years of monthly administrative data on IA receipt. As such, it is possible to evaluate IA outcomes at a monthly basis as well as potentially looking at employment in between the final two surveys, subject to the caveat that retrospective data may contain measurement error. Evaluating the effectiveness of social networks at other points in time may be of interest since numerous evaluation studies that examined the impacts of other active labour market policies including those many governments have introduced to reduce high levels of unemployment generally find that the estimated impacts that are obtained in the months after these programs are introduced differ from those witnessed in the medium to long term. For example, Lechner et al. (2011) using German data reports that a specific intensive training program which provided skills required for a different profession than the one currently held by participants, led to a sustained increase in employment rates eight years into the post-program period; whereas he also reports that the effects from other skills training programs in Germany decline over time. As such, we additionally conduct a preliminary investigation to see if the estimated effects are sensitive to the timing of the final survey.

\footnotetext{
${ }^{13}$ There is a large literature that models the formation of social networks and the process by which information is transmitted or exchanged among members.
} 
To motivate our empirical analyses, we hypothesize the following channel through which social networks affect labour market outcomes. As in a traditional labour supply model, we assume that individuals make decisions on whether to work by maximizing their utility subject to both a budget and time constraint. Workers face a trade-off between allocating their time between leisure activities and income generating activities. Social networks enter the model by affecting the probability an individual can find a job. That is, while searching for employment, the odds that an individual will obtain employment are influenced by size of the individual's social network. For example, social contacts may transmit information on the availability of jobs which might not be well-advertised, or provide referrals to firms to mitigate moral hazard. Social networks could also affect other labour market outcomes such as wage offers by providing the individuals with knowledge on the degree of their bargaining power. ${ }^{14}$ An individual will decide to take employment if $Y_{i t}^{*}$, the latent latent utility differential between working and not working exceeds zero.

We define $Y_{i t}$ to be an indicator variable for individual $i$ that is unity if she is employed 54 months after the start of the experiment. That is, the analyst does not observe $Y_{i t}^{*}$ but does see $Y_{i t}=1$ if person $i$ in period $t$ is employed and $Y_{i t}=0$ if not. Our primary estimating equation takes the form

$$
Y_{i t}=\beta_{0}+\beta_{1} \Delta S N_{i t-1}+\beta_{2} \mathbf{X}_{i t}+\epsilon_{i t}
$$

where $\Delta S N_{i t-1}$ is a measure of how network resources accessed by individual $i$ changed between the start of the experiment and when interviewed 40 months later. The matrix $X$ includes numerous demographic control variables and $\epsilon_{i t}$ is a random error term with mean zero. OLS estimates of equation (1) may yield biased estimates of $\beta_{1}$ since unobserved

\footnotetext{
${ }^{14}$ There is substantial theoretical research on the various channels that contacts in the labor market may be beneficial. For example, Mortensen and Vishwanath (1994) and Calvo-Armengol and Jackson $(2004,2007)$ claim they allow workers to more effectively sample a given wage distribution and Holzer (1988) suggests that they improve search efficiency.
} 
characteristics such as motivation and other non cognitive skills may affect both labour force participation and the ability to increase the size of one's social network.

In our analyses we consider four alternative measures of $\triangle S N_{i t}$ to shed light on the relative importance of weak versus strong ties. We consider changes between the baseline survey and the end of the experiment survey in the total number of: i) contacts and acquaintances; ii) contacts and acquaintances that can provide specialized advice and help participants find a job; iii) contacts that are family members or friends; and iv) contacts that reside in same community as the respondent. Ex ante, we would expect that the CEIP intervention would be most likely to affect the total number of contacts and acquaintances that can help provide specialized advice and can help participants find a job and least likely to influence the total number of contacts that are family members or friends.

To overcome the hurdles introduced by the endogeneity of $\triangle S N_{i t}$, we consider an instrumental variables procedure. The identification strategy of this paper relies on the fact that the CEIP project introduced a source of exogenous variation in the size of participants' social networks. It is reasonable to postulate that those assigned to the treatment intervention may have been in a better position to develop links by meeting potential contacts, including project sponsors, training organizations and other participants, some of whom possessed extensive social networks and occupied positions of influence in their respective communities. ${ }^{15}$ We hypothesize that the project is likely to have changed bridging and linking social capital of some individuals by providing them greater opportunities to form weak ties, or reducing the transaction costs to doing so. Assignment to the CEIP treatment should have less influence on the size of social capital that constitute strong ties.

\footnotetext{
${ }^{15}$ For paid Program group volunteers, the project also altered their social capital through the succession of assignments to community-based projects. But these volunteers, if randomly selected in the community survey, were excluded in order not to confound the effect of networks on employment.
} 
Thus, our identification relies on the instrument, assignment to the treatment programs is truly random. Holland (1988) termed this identification strategy as an encouragement design, since subjects are randomly selected and encouraged to take the treatment, but it is the effects of the treatment itself, not the effects of encouragement, which are of interest. Thus, the selection bias that arises in accepting the treatment is removed via the instrumental variables analysis, as not all those who are encouraged to attend comply. Randomization of the instruments is not sufficient on its own and for the instruments to be valid they must affect the outcome only by manipulating the treatment.

It is important to note that we can not recover the structural parameters of the model underlying our analysis and we will be estimating reduced form impacts. As our interest is in the causal effect of social networks, and there is likely treatment effect heterogeneity, one can interpret the resulting IV estimates as local average treatment effects. ${ }^{16}$ Since it is reasonable to assume that there may be heterogeneity in the impacts of changes in the size of one's social network on labour market outcomes on the basis of the initial size of

\footnotetext{
${ }^{16}$ Structural analyses would require us to consider the complete network structure of individuals, with data on the number of contacts of various types and a topography of who is linked to whom. Montgomery (1992) argues that the importance of weak ties can only be understood if one considers the entire network structure of individuals, subject some of them to an experimental variation, and examine the outcomes. Jackson (2009) suggests that the "reflection problem" defined in Manski (1993) can partly be overcome with more complete observation of the network patterns in a society, so that a given individual's peers can be directly observed and need not be inferred from the individual's own characteristics. It is important to highlight that we are relying on instruments to introduce variation in the social networks of our respondents that is exogenous to their current labour market behaviour. Recall, our identification is coming from the group of respondents whose treatment status (social networks) changes due to the instruments, in particular the ones reflecting their involvement with the project. This interpretation of the role of the project is in line with Johnson (2003) who finds that potentially beneficial (but distant) connections are often too costly to establish and maintain, and that the project (CEIP) can make such connections less costly. The project thus helped the participants to build bridging and linking social networks which, in turn, may have opened up access to subsequent labour market resources.
} 
the experiment, as well as other baseline characteristics, we will also conduct our analyses based on subsamples defined by characteristics measured in the baseline survey.

\section{Results}

Examining the sample sizes across the bottom row of Table 1, we observe a large proportion of individuals in the baseline sample were not followed up in subsequent cycles. Further, the rate of follow-up differed between those assigned to the intervention and the control groups. As such, it is reasonable to have concerns that selective attrition may bias our estimates of equation (1). To examine whether participants left the experiment in a non-random manner, we use the procedure developed in Becketti et al. (1988) to test for attrition due to observables. ${ }^{17}$ This procedure involves OLS estimation of an equation using data from the baseline survey. Specifically, we are interested in whether treatment assignment, individual characteristics and social network variables differentially affected the likelihood of holding a job at baseline. In the estimating equation we allow subsequent attritors to have differential effects. The results on an F-test, examining whether participants who left the CEIP study after the collection of baseline data are systematically different than those who remained in the study in terms of initial behavioral relationships, determine if we need to account for selection on observables.

The results of the test for selective attrition are presented in Table 3. The columns differ based on the measure of social network being investigated. In the second row from the bottom of Table 3 the results from the F-tests of the joint significance of these interaction terms are presented. For each social network measure we are unable to reject the hypothesis that the coefficient vector is significantly different for attritors from nonattritors. As such, there is no evidence to suggest that attrition patterns differed between

\footnotetext{
${ }^{17}$ This test was also used in Ding and Lehrer (2010) who additionally provide a more intuitive explanation of the procedure.
} 
groups, allowing us to confidently treat all missing data as being random. As can be observed in Table 3, it is interesting to note that both males and those with higher levels of education were less likely to hold a job at the baseline survey.

Instrumental variable estimates of equation (1) are presented in Table 4 . With the exception of the last column examining the change in the number of contacts residing in the same community, all social network variables are negatively related to holding a job 18 months following the experiment completion. However, none of the impacts of changes in social network variables are statistically significant. Controlling for other factors, we observe that individuals from the EI sample and those with higher levels of education are now associated with holding a job. For comparison, OLS estimates of equation (1) that treat the changes in the social network variables as being exogenous are presented in Table 5. Notice that all of the social network variables are positively related to holding a job 18 months following the CEIP experiment. However, only the effect of the changes in the number of contacts who can help find a job is statistically significant at the $10 \%$ level.

To assess the suitability of being randomly assigned to the CEIP treatment as an instrument for the change in each measure of social network, we consider a simple OLS regression of the first stage regression and run an F-test for the joint significance of the instrument. The results for each of the respective social network measures are presented in Table 6. The coefficients on all of the explanatory variables in the first stage regression including the instruments are reasonable in sign and magnitude. The instruments are statistically significant predictors of changes in the number of members in one's network that can help find jobs and the number of acquaintances, and the F-statistics on its significance is respectively above current cutoffs (i.e. Staiger and Stock (1997)) for weak instruments. Not surprisingly, assignment to the CEIP did not significantly affect the number of contacts who were friends and families or who lived in the same community as the respondent. Since the reliability of our estimates depends directly on the validity of 
our instrument, the low F-statistic for these measures is a concern, since it may indicate weak identification. ${ }^{18}$

To examine whether changes in the size of social network measures heterogeneously impacted the likelihood of having a job for individuals with different education levels, initial size of the social network and gender, we replicated the above analyses on subsamples defined by these criteria. We found the first stage relationships between both changes in the number of acquaintances and changes in the number of contacts who can help find jobs were strongest for both females and those with education levels above the secondary school. ${ }^{19}$ For all other subsamples based on observed criteria we did not witness a heterogenous relationship. However, while the first stage relationships were quite strong for these subsamples, Table 7 demonstrates there were no changes in either the instrumental variable (top panel) or OLS (bottom panel) estimates of equation (1) for either subsample. Most striking is the pattern observed for females in which the OLS estimates indicate a statistically significant positive relationship with having a job, whereas the IV estimates are statistically insignificant.

We next examined the robustness of our results to measuring labour market outcomes at different points in time. The time-varying pattern of the estimated impacts of the CEIP intervention appear to decline slightly on a gradual basis from months 41 to $54 .{ }^{20}$ These

\footnotetext{
${ }^{18}$ Weak identification could result in i) the IV estimates being inconsistent and biased towards the OLS estimates, and ii) the test statistics for inference are inaccurate. We attempted to correct the statistical inference problem using the Moreira (2003) conditional approach to construct tests of coefficients based on the conditional distributions of nonpivotal statistics. If the instruments have low strength then the confidence intervals should increase relative to those based on standard asymptotic theory. We find that the length of the $95 \%$ confidence interval increased by roughly $30 \%$ for both of these change in network variables, a small margin which increases our confidence in the validity of the instrument. These diagnostics suggest that it is unlikely that the estimates for these two network variables are due to a poor instrument.

${ }^{19}$ For space considerations, these results are available from the authors upon request.

${ }^{20}$ For space considerations, results are available from the authors upon request.
} 
results are consistent with those reported by Card and Hyslop (2009) who examined a different Canadian program that provided a high-powered earnings subsidy for long-term welfare recipients who resided in areas around Vancouver, British Columbia and southern New Brunswick. These authors find that the earnings subsidy significantly increased full time employment and lowered welfare participation in the short-run but that these effects declined over time and six years post-program the effects became negligible. Yet, additional evaluation is required to determine if the magnitude and statistical significance of the effects from the CEIP program would change as even more post program data is made available.

Finally, we considered direct estimation of the reduced form of the instrumental variables model estimated in Table 4 . That is, we estimate

$$
Y_{i t}=\beta_{0}+\beta_{1} \text { Treat }_{i}+\beta_{2} \mathbf{X}_{i t}+\epsilon_{i t}
$$

where Treat $_{i}$ is an indicator if an individual was assigned to the CEIP treatment group. Thus, OLS estimates $\beta_{1}$ can be interpreted as an intent to treat parameter, providing us with the causal effect of being assigned to the CEIP treatment. This equation is estimated using the full 54-month sample as well as subsamples defined on the basis of predetermined characteristics. The results for a subset of these outcomes are presented in Table 8. Note that, as shown in the first column, assignment to the CEIP treatment does not significantly increase the likelihood of holding a job for the full sample. However, there are three subsamples in which we observe that assignment to the CEIP treatment significantly lowered the odds of being employed. These subsamples include: i) those with degrees above the secondary level; ii) those who experienced larger changes in the size of their social networks based on the number of friends and family members; and iii) those who experienced larger changes in the size of their social networks based on the number of individuals living in the same community. The last two results are suggestive 
evidence that increases in the size of strong ties do not boost labour market outcomes. Interestingly, the results reported in Table 8, in conjunction with those presented in Table 6 , suggest that, while the size of these types of social networks were not directly affected by the experiment itself, changes in social network size does impact the probability of finding stable employment.

Taken together, the results in this subsection suggest that increasing the size of weak ties in one's social network is indeed possible for policymakers. These increases are larger for those with more education and females. However, these increases in the social network variables do not boost the likelihood of holding a job 18 months later. These results differ from conclusions in the final SRDC evaluation (Guyamarti et al. 2008a, pp. 7) such as: "It was uncertain, however, whether CEIP could improve skills and networks and whether this would increase post-program employment in an economically depressed area". While we did not find significant post-program impacts on the employment of individual program participants, we now consider whether the CEIP program had impacts on the broader labour market.

\subsection{Community Level Analysis}

The final question we examine is whether the CEIP program had long term impacts on the size of social networks and levels of employment variables across communities in Nova Scotia. Using data from the CEIP community sample we estimate the following equation:

$$
\triangle Y_{i t}=\beta_{0}+\beta_{1} C E I P_{i t}+\beta_{2} X_{i t}+\varepsilon_{i t}
$$

where $C E I P_{i t}$ is an indicator if an individual lives in one of the communities where the CEIP program took place, $X_{i t}$ is a vector of individual characteristics and $\varepsilon_{i t}$ is a random disturbance term with mean zero. Since the control and CEIP communities were selected on the basis of observed characteristics, we assume that selection on observables holds and 
use OLS to estimate equation (3). We are interested in determining whether estimates of $\beta_{1}$ are significantly different from zero. The outcomes we consider include alternative measures of change in the size of social networks and four measures of employment as outcome variables. We conduct the analyses with the full CEIP community survey sample and the results are robust to the exclusion of the subset of individuals who also were participating in the CEIP experiment. In total, there are 46 sample members who were assigned to the CEIP treatment and 23 individuals who were in the CEIP control group. ${ }^{21}$

Estimates of $\beta_{1}$ from equation (3) are presented in Table 9. Each row of the table corresponds to a different outcome variable. The community level results indicate that the CEIP program did indeed increase the size of a few specific types of social network measures across communities. There are large and significant increases in the number of both linking and bridging contacts as well as a marginally significant increase in the number of contacts who can help find a job. All of these measures correspond to weak ties. In contrast, the size of bonding networks which correspond to strong ties did not increase nor did the overall network size in a different manner across the community types. Even those not involved in the community made new connections, indicating that all of the increases in social networks exhibited during the time the programs were instituted within the community were through weak ties.

At the same time, the results in table 9 also indicate that there were no aggregate changes in many of the employment outcomes across communities. The percentage of

\footnotetext{
${ }^{21}$ It is worth repeating that the distinction between these communities lies in the fact that, whereas program communities received community projects, comparison communities did not. However, those who were involved with CEIP in any capacity, whether as participants or in other paid or unpaid capacities, could belong to any community. Therefore, though we find a greater proportion of respondents from the program communities connected in some way to the CEIP, we do find a significant number of respondents from the comparison communities as well with some connection to the CEIP. In fact, there is a greater proportion of respondents from the comparison communities who have non-paid involvement with the CEIP than there is from the program communities.
} 
the sample holding a full time job and an hourly salary did not significantly differ across the community types. In fact, from baseline to 18 months post-experimental completion, CEIP communities exhibited slight decreases in the percentage of individuals holding part time jobs and the number of hours worked per week. On average, compared to baseline measures, CEIP community members worked roughly 1.5 hours less per week 18 months following study completion, compared to members of the comparison communities. Recall that the statistics displayed in table 2 indicated that these differences in hours worked, but not in wage rates, were also observed in the first wave data, meaning the CEIP intervention did not seem to affect these outcomes three years after intervention commencement. While these results appear disappointing, they should not be surprising. The additional salaries individuals earned on CEIP jobs, relative to transfer payments, were both temporary and small. Accordingly, any multiplier effects that would occur through consumption channels are unlikely to affect employment levels.

Last, we did investigate whether there were differences in the characteristics of those employed in CEIP program and comparison communities using multivariate regressions that conditioned for all of the covariates in $X$ from equation (3) as well as social network variables. We did find several significant differences during the first survey $(\mathrm{F}=2.09$, Prob $>\mathrm{F}=0.0067)$ and second survey $(\mathrm{F}=3.28$, Prob $>\mathrm{F}=0.0000)$ but by the last survey there was no significant link between the 16 explanatory variables and community status $(\mathrm{F}=1.20$, Prob $>\mathrm{F}=0.2628)$. While suggestive, this evidence continues to reinforce the finding from the CEIP individual impact study that this intervention only served to change who was holding a job post-experiment. ${ }^{22}$

\footnotetext{
${ }^{22}$ We speculate that a fraction of the estimated effects of social network variables commonly found in empirical analyses may be capturing the impacts of non-cognitive skills that are rewarded in workplaces that employ team production.
} 


\section{Conclusion}

This paper uses data from the Community Employment Innovation Project (CEIP) to estimate how changes in the size of social network affect employment 18 months following the CEIP intervention. Our results provide evidence that access to the CEIP program led to gains in the size of the number of weak ties, particularly for women and those who completed education beyond secondary school. However, these changes in social network size did not translate into improved post-experiment employment outcomes. Within the labour market, we do observe small but significant changes in the composition of workers who held jobs 18 months after study completion. Individuals assigned to the CEIP treatment were significantly less likely to find employment if they either: i) experienced larger gains in the size of their strong ties during the experiment; or ii) held a degree above the secondary school level. As such, the long term impacts of the CEIP study can be simply summarized as follows: the program did not change the size of the pie, but rather changed who got the slices. ${ }^{23}$ While notions that increasing social capital and reducing social exclusion lead to economic prosperity pervade many disciplines, this analysis suggests that other avenues such as economic growth or job creation remain the best solution to reducing poverty.

Our analyses at the community level reinforce these findings. Community level analyses indicate that measures of alternative types of social networks do increase at a faster rate in program communities relative to comparison communities. However, we did not observe aggregate changes in the number of individuals employed across communities. At best, policy changes along the CEIP dimension likely only have distributional consequences regarding who is employed locally in the long-run.

Recent reforms to Canada's EI system appear to have been developed on the premise

\footnotetext{
${ }^{23}$ These results are similar to findings from other labour market policy experiments conducted in other countries such as Crépon et al (2012) who term this as displacement effects.
} 
that a different dimension of social capital, namely regional attachment, influences labour market prospects. That is, individuals who have strong preferences for living in a given community decrease their mobility, thereby increasing unemployment. The CEIP data may be able to shed light on the extent to which local preferences influence the likelihood of being unemployed since the data contains many measures of the number of years one has both lived on Cape Breton Island and the number of contacts on the island. In addition, we wish to explore whether social networks have a significant impact on individuals' subsequent welfare participation. Contacts in one's social network may provide more information about welfare eligibility than job availability, since there is no crowding out of economic opportunity. Finally, the degree to which different forms of information flow in social networks remain largely understudied despite the relevance of this area of inquiry. Information flow can affect individual behavior towards welfare participation through two important channels: information and norms. This presents an agenda for future research. 


\section{References}

[1] Abbott, Michael, and Charles M. Beach (2008), "Immigrant Earnings Distributions and Earnings Mobility in Canada: Evidence for the 1982 Landing Cohort from IMDB Micro Data," Canadian Labour Market and Skills Researcher Network Working Paper 13.

[2] Abbott, Michael, and Charles M. Beach (2011), "Immigrant Earnings Differences across Admission Categories and Landing Cohorts in Canada," Canadian Labour Market and Skills Researcher Network Working Paper 81.

[3] Angelucci, Manuela, and Giacomo De Giorgi (2009), "Indirect Effects of an Aid Program: How do Cash Transfers Affect Ineligibles' Consumption?," American Economic Review 99(1), 486-508.

[4] Angrist, Joshua D., Guido W. Imbens, and Donald B. Rubin (1996), "Identification of Causal Effects Using Instrumental Variables," Journal of the American Statistical Association 91(434), 444-55.

[5] Apinunmahakul, Amornrat and Rose Anne Devlin (2008), "Social Networks and Private Philanthropy," Journal of Public Economics 92(1-2), 309-328.

[6] Bayer, Patrick, Stephen L Ross and Giorgio Topa (2008), "Place of Work and Place of Residence: Informal Hiring Networks and Labour Market Outcomes," Journal of Political Economy 116(6), 1150-1196.

[7] Beaman, Lori, (2012), "Social Networks and the Dynamics of Labour Market Outcomes: Evidence from Refugees Resettled in the U.S," Review of Economic Studies 79(1), 128-161.

[8] Becketti, Sean, William Gould, Lee Lillard and Finis Welch (1998), "The Panel Study of Income Dynamics after Fourteen Years: An Evaluation," Journal of Labor Economics 6(4), 472-492.

[9] Calvo-Armengol, Antoni, and Matthew Jackson (2004), "The Effects of Social Networks on Employment and Inequality," American Economic Review 94(3), 426-454.

[10] Calvo-Armengol, Antoni, and Matthew Jackson (2007), "Networks in Labor Markets: Wage and Employment Dynamics and Inequality," Journal of Economic Theory $132(1), 27-46$.

[11] Card, David and Dean R. Hyslop (2009), "The Dynamic Effects of an Earnings Subsidy for Long-Term Welfare Recipients: Evidence from the Self Sufficiency Project Applicant Experiment," Journal of Econometrics 153(1), 1-20. 
[12] Case, Anne, and Lawrence Katz (1991), "The Company You Keep: The Effects of Family and Neighborhood on Disadvantaged Youths," NBER Working Paper No. 3705.

[13] Crépon, Bruno, Esther Duflo, Marc Gurgand, Roland Rathelot and Philippe Zamora (2012), "Do Labor Market Policies Have Displacement Effects? Evidence from a Clustered Randomized Experiment," NBER Working Paper No. $1859 \%$.

[14] Datcher, Linda, (1982), "Effects of Community and Family Background on Achievement," Review of Economics and Statistics 64(1), 32-41.

[15] Ding, Weili and Steven F Lehrer (2010), "Estimating Treatment Effects from Contaminated Multiperiod Education Experiments: The Dynamic Impacts of Class Size Reductions," The Review of Economics and Statistics 92(1), 31-42.

[16] Duflo, Esther and Emmanuel Saez (2003), "The Role of Information and Social Interactions in Retirement Plan Decisions: Evidence from a Randomized Experiment," Quarterly Journal of Economics 118(3), 815-842.

[17] Garg, Rajiv and Rahul Telang (2011), "To Be or Not To Be Linked on LinkedIn.com: Job Search Using Online Social Networks," mimeo, Carnegie Mellon University.

[18] Granovetter, Mark S. (1973), "The Strength of Weak Ties," American Journal of Sociology," 78(6), 1360-1380.

[19] Granovetter, Mark S. (1995), Getting a Job: A Study of Contacts and Careers, Cambridge, MA: Harvard University Press.

[20] Greenwood, John, Claudia Nicholson, David Gyarmati, Darrell Kyte, Melanie MacInnis, Reuben Ford (2003), "The Community Employment Innovation Project: Design and implementation," Ottawa: Social Research and Demonstration Corporation.

[21] Gyarmati, David, Shawn de Raaf, Claudia Nicholson Darrell Kyte and Melanie MacInnis (2006), "Community Employment Innovation Project (CEIP) - Testing a Community-Based Jobs Strategy for the Unemployed: Early Impacts of CEIP," Ottawa, ON: Social Research and Demonstration Corporation.

[22] Gyarmati, David, Shawn de Raaf, Claudia Nicholson, Boris Palameta, Taylor ShekWai Hui and Melanie MacInnis (2007), "Community Employment Innovation Project (CEIP) - Improving Skills, Networks, and Livelihoods through Community-Based Work: Three-Year Impacts of CEIP," Ottawa, ON: Social Research and Demonstration Corporation. 
[23] Gyarmati, David, Shawn de Raaf, Boris Palameta, Claudia Nicholson and Taylor Shek-Wai Hui (2008a), "Community Employment Innovation Project (CEIP) - Encouraging Work and Supporting Communities: Final Results of CEIP," Ottawa, ON: Social Research and Demonstration Corporation.

[24] Gyarmati, David, Shawn de Raaf, Boris Palameta, Claudia Nicholson, Taylor ShekWai Hui, Darrell Kyte and Melanie MacInnis (2008b), "Community Employment Innovation Project (CEIP) - Engaging Communities in Support of Local Development: Measuring the Effects of the Community Employment Innovation Project on Communities," Ottawa, ON: Social Research and Demonstration Corporation.

[25] Heckman, James J. (1997), "Instrumental Variables: A Study of Implicit Behavioral Assumptions in One Widely Used Estimator," Journal of Human Resources 32(3), 441-462.

[26] Holland, Paul W. (1988), "Causal Inference, Path Analysis, and Recursive Structural Equations Models," Sociological Methodology 18, 449-484.

[27] Holzer, Harry (1988), "Search Method Use by Unemployed Youth," Journal of Labor Economics 6(1), 1-20.

[28] Ioannides, Yannis and Linda Datcher Loury (2004), "Job Information Networks, Neighborhood Effects and Inequality," Journal of Economic Literature 42(4), 10561093.

[29] Jackson, Matthew O. (2008), Social and Economic Networks, Princeton University Press.

[30] Jackson, Matthew O. (2010), "An Overview of Social Networks and Economic Applications," in the The Handbook of Social Economics, edited by J. Benhabib, A. Bisin, and M.O. Jackson, North Holland Press.

[31] Laschever, Ron (2009), "The Doughboys Network: Social interactions and Labor Market Outcomes of World War I Veterans," mimeo, University of Illinois, UrbanaChampain.

[32] Lechner, Michael, Ruth Miquel and Conny Wunsch (2011), "Long-Run Effects of Public Sector Sponsored Training in West Germany," Journal of the European Economic Association 9(4), 742-784.

[33] Manski, Charles F. (1993), "Identification of Endogenous Social Effects: The Reflection Problem," Review of Economic Studies 60(3), 531-542. 
[34] Miguel, Edward and Michael Kremer (2003), "Worms: Identifying Impacts on Education and Health in the Presence of Treatment Externalities," Econometrica 72(1), 159-217.

[35] Montgomery, James D. (1991), "Social Networks and Labor-Market Outcomes: Toward an Economic Analysis," American Economic Review 81(5), 1408-1418.

[36] Montgomery, James D. (1992), "Job Search and Network Composition: Implications of the Strength of Weak Ties Hypothesis," American Sociological Review 57(3), 586596.

[37] Mortensen, Dale and Tara Vishwanath (1994), "Personal Contacts and Earnings: It is Who you Know!," Labour Economics 1(2), 187-201.

[38] Staiger, Douglas, Stock, James H. (1997), "Instrumental Variables Regression with Weak Instruments," Econometrica 65(3), 557-586.

[39] Tassier, Troy (2006), "Labor Market Implications of Weak Ties," Southern Economic Journal 72(3), 704-719.

[40] Topa, Giorgio (2001), "Social Interactions, Local Spillovers, and Unemployment," Review of Economic Studies 68(2), 261-295. 
Table 1: Summary Statistics on Individuals from the CEIP Experimental Dataset

\begin{tabular}{|c|c|c|c|c|c|c|c|c|}
\hline \multirow{2}{*}{ Variable } & \multicolumn{4}{|c|}{ Treatment Group } & \multicolumn{4}{|c|}{ Control Group } \\
\hline & Wave 1 & Wave 2 & Wave 3 & Wave 4 & Wave 1 & Wave 2 & Wave 3 & Wave 4 \\
\hline Holds a job & $\begin{array}{c}.1834 \\
(.3873)\end{array}$ & $\begin{array}{c}.8501 \\
(.3573)\end{array}$ & $\begin{array}{l}.4132 \\
(.4928)\end{array}$ & $\begin{array}{c}.4791 \\
(.5)\end{array}$ & $\begin{array}{l}.1717 \\
(.3774)\end{array}$ & $\begin{array}{c}.4604 \\
(.4988)\end{array}$ & $\begin{array}{c}.4852 \\
(.5002)\end{array}$ & $\begin{array}{l}.5036 \\
(.5004)\end{array}$ \\
\hline Number of contacts that can help find a job & $\begin{array}{c}6.6045 \\
(6.3192)\end{array}$ & $\begin{array}{c}9.698 \\
(7.6888)\end{array}$ & $\begin{array}{c}11.8809 \\
(12.5964)\end{array}$ & $\begin{array}{c}9.3746 \\
(10.2605)\end{array}$ & $\begin{array}{c}6.7517 \\
(6.5463)\end{array}$ & $\begin{array}{c}9.8493 \\
(9.8832)\end{array}$ & $\begin{array}{c}10.2682 \\
(11.9707)\end{array}$ & $\begin{array}{c}8.2332 \\
(8.5255)\end{array}$ \\
\hline Number of contacts family and friends & $\begin{array}{c}8.623 \\
(8.759)\end{array}$ & $\begin{array}{l}10.2794 \\
(8.7469)\end{array}$ & $\begin{array}{c}11.303 \\
(10.4786)\end{array}$ & $\begin{array}{l}10.438 \\
(10.23)\end{array}$ & $\begin{array}{c}8.5373 \\
(7.1162) \\
\end{array}$ & $\begin{array}{c}9.9045 \\
(8.0668)\end{array}$ & $\begin{array}{c}10.8579 \\
(10.5321)\end{array}$ & $\begin{array}{c}9.875 \\
(9.0037)\end{array}$ \\
\hline Number of contacts that are acquaintances & $\begin{array}{c}1.5562 \\
(2.8443)\end{array}$ & $\begin{array}{l}1.6714 \\
(4.2954)\end{array}$ & $\begin{array}{c}2.6442 \\
(6.3517)\end{array}$ & $\begin{array}{c}1.5122 \\
(3.8766)\end{array}$ & $\begin{array}{c}1.8507 \\
(3.2964)\end{array}$ & $\begin{array}{c}1.8799 \\
(5.9908)\end{array}$ & $\begin{array}{c}2.0474 \\
(5.9809)\end{array}$ & $\begin{array}{c}1.319 \\
(2.9679)\end{array}$ \\
\hline $\begin{array}{l}\text { Number of contacts in same community as } \\
\text { respondent }\end{array}$ & $\begin{array}{c}7.1104 \\
(9.4029)\end{array}$ & $\begin{array}{c}7.8721 \\
(8.1458)\end{array}$ & $\begin{array}{c}9.284 \\
(10.4105)\end{array}$ & $\begin{array}{c}7.1825 \\
(8.1714)\end{array}$ & $\begin{array}{c}6.8944 \\
(7.7253)\end{array}$ & $\begin{array}{c}7.2925 \\
(7.3939)\end{array}$ & $\begin{array}{c}9.1048 \\
(9.9673)\end{array}$ & $\begin{array}{l}7.0579 \\
(7.701)\end{array}$ \\
\hline Holds a university degree & $\begin{array}{c}.0423 \\
(.2013) \\
\end{array}$ & $\begin{array}{c}.041 \\
(.1985) \\
\end{array}$ & $\begin{array}{l}.0399 \\
(.196) \\
\end{array}$ & $\begin{array}{c}.0484 \\
(.2148) \\
\end{array}$ & $\begin{array}{c}.0291 \\
(.1681) \\
\end{array}$ & $\begin{array}{c}.032 \\
(.1762) \\
\end{array}$ & $\begin{array}{c}.0295 \\
(.1692) \\
\end{array}$ & $\begin{array}{c}.0289 \\
(.1678)\end{array}$ \\
\hline Respondent is single & $\begin{array}{c}.358 \\
(.4797)\end{array}$ & $\begin{array}{l}.3437 \\
(.4753)\end{array}$ & $\begin{array}{l}.3287 \\
(.4701)\end{array}$ & $\begin{array}{l}.3088 \\
(.4624)\end{array}$ & $\begin{array}{c}.3474 \\
(.4765)\end{array}$ & $\begin{array}{l}.3232 \\
(.468)\end{array}$ & $\begin{array}{c}.329 \\
(.4702)\end{array}$ & $\begin{array}{l}.3056 \\
(.4611)\end{array}$ \\
\hline Respondent is divorced & $\begin{array}{l}.1783 \\
(.383) \\
\end{array}$ & $\begin{array}{c}.181 \\
(.3853) \\
\end{array}$ & $\begin{array}{l}.1782 \\
(.383) \\
\end{array}$ & $\begin{array}{c}.1836 \\
(.3875) \\
\end{array}$ & $\begin{array}{c}.1982 \\
(.3989) \\
\end{array}$ & $\begin{array}{c}.1966 \\
(.3978) \\
\end{array}$ & $\begin{array}{c}.1899 \\
(.3925) \\
\end{array}$ & $\begin{array}{l}.1917 \\
(.394) \\
\end{array}$ \\
\hline Respondent is male & $\begin{array}{l}.5363 \\
(.499) \\
\end{array}$ & $\begin{array}{c}.5262 \\
(.4997)\end{array}$ & $\begin{array}{l}.5238 \\
(.4998) \\
\end{array}$ & $\begin{array}{c}.5159 \\
(.5002)\end{array}$ & $\begin{array}{c}.4954 \\
(.5003)\end{array}$ & $\begin{array}{c}.4619 \\
(.4989) \\
\end{array}$ & $\begin{array}{l}.4419 \\
(.497)\end{array}$ & $\begin{array}{c}.4448 \\
(.4974)\end{array}$ \\
\hline Respondent source of sample is ei (vs. ia) & $\begin{array}{c}.6592 \\
(.4743)\end{array}$ & $\begin{array}{c}.6648 \\
(.4724)\end{array}$ & $\begin{array}{c}.6774 \\
(.4678)\end{array}$ & $\begin{array}{l}.7028 \\
(.4574)\end{array}$ & $\begin{array}{c}.6592 \\
(.4743)\end{array}$ & $\begin{array}{c}.6524 \\
(.4766)\end{array}$ & $\begin{array}{c}.671 \\
(.4702)\end{array}$ & $\begin{array}{c}.6835 \\
(.4655)\end{array}$ \\
\hline Respondent has high school diploma & $\begin{array}{c}.2606 \\
(.4392) \\
\end{array}$ & $\begin{array}{l}.2578 \\
(.4377) \\
\end{array}$ & $\begin{array}{c}.2662 \\
(.4423) \\
\end{array}$ & $\begin{array}{c}.2492 \\
(.4329) \\
\end{array}$ & $\begin{array}{c}.2927 \\
(.4553) \\
\end{array}$ & $\begin{array}{c}.2997 \\
(.4585) \\
\end{array}$ & $\begin{array}{c}.3148 \\
(.4648) \\
\end{array}$ & $\begin{array}{c}.3043 \\
(.4605) \\
\end{array}$ \\
\hline Respondent has college diploma & $\begin{array}{l}.1136 \\
(.3175)\end{array}$ & $\begin{array}{c}.1089 \\
(.3117)\end{array}$ & $\begin{array}{l}.1121 \\
(.3158)\end{array}$ & $\begin{array}{l}.1135 \\
(.3175)\end{array}$ & $\begin{array}{l}.1466 \\
(.354)\end{array}$ & $\begin{array}{c}.1448 \\
(.3522)\end{array}$ & $\begin{array}{c}.1489 \\
(.3563)\end{array}$ & $\begin{array}{c}.1555 \\
(.3627)\end{array}$ \\
\hline Respondent lived at current address yrs. & $\begin{array}{c}12.9841 \\
(13.6296) \\
\end{array}$ & $\begin{array}{c}13.255 \\
(13.6367) \\
\end{array}$ & $\begin{array}{l}13.3746 \\
(13.727) \\
\end{array}$ & \begin{tabular}{|c|}
13.7851 \\
$(13.9568)$ \\
\end{tabular} & \begin{tabular}{|c|}
12.3342 \\
$(13.0661)$ \\
\end{tabular} & $\begin{array}{c}12.532 \\
(12.9349)\end{array}$ & $\begin{array}{c}12.8404 \\
(13.1559) \\
\end{array}$ & $\begin{array}{l}13.1917 \\
(13.335) \\
\end{array}$ \\
\hline Years lived on Cape Breton Island & $\begin{array}{c}34.9076 \\
(12.9816)\end{array}$ & $\begin{array}{c}35.3426 \\
(13.0418)\end{array}$ & $\begin{array}{c}35.6692 \\
(13.0484)\end{array}$ & \begin{tabular}{|c|}
35.7958 \\
$(13.4166)$
\end{tabular} & \begin{tabular}{|c|}
34.4523 \\
$(13.1209)$
\end{tabular} & $\begin{array}{c}35.281 \\
(12.6446)\end{array}$ & $\begin{array}{c}34.8383 \\
(12.8966)\end{array}$ & $\begin{array}{c}35.5655 \\
(12.9163)\end{array}$ \\
\hline Number of relatives living in Cape Breton & $\begin{array}{c}.9841 \\
(.1253)\end{array}$ & $\begin{array}{c}.9829 \\
(.1296)\end{array}$ & $\begin{array}{l}.9815 \\
(.135)\end{array}$ & $\begin{array}{c}.9815 \\
(.1348) \\
\end{array}$ & $\begin{array}{c}.9574 \\
(.2021) \\
\end{array}$ & $\begin{array}{l}.9677 \\
(.177)\end{array}$ & $\begin{array}{c}.9653 \\
(.1831)\end{array}$ & $\begin{array}{c}.969 \\
(.1735)\end{array}$ \\
\hline Observations & 757 & 707 & 651 & 599 & 757 & 656 & 611 & 553 \\
\hline
\end{tabular}

Note: Standard deviations in parentheses 
Table 2: Summary Statistics on Individuals from the CEIP Community Survey

\begin{tabular}{|c|c|c|c|c|c|c|}
\hline Variable & Wave 1 IN & Wave 2 IN & Wave 3 IN & Wave 1 OUT & Wave 2 OUT & Wave 3 OUT \\
\hline Total bonding contacts & $\begin{array}{l}23.324 \\
(24.974)\end{array}$ & $\begin{array}{l}21.368 \\
(21.878)\end{array}$ & $\begin{array}{l}20.618 \\
(20.771)\end{array}$ & $\begin{array}{l}25.437 \\
(30.778)\end{array}$ & $\begin{array}{l}22.548 \\
(23.979)\end{array}$ & $\begin{array}{l}22.400 \\
(23.946)\end{array}$ \\
\hline Total bridging contacts & $\begin{array}{l}4.202 \\
(6.041)\end{array}$ & $\begin{array}{l}4.087 \\
(6.036)\end{array}$ & $\begin{array}{l}4.245 \\
(6.508)\end{array}$ & $\begin{array}{l}5.008 \\
(9.146)\end{array}$ & $\begin{array}{l}4.613 \\
(6.834)\end{array}$ & $\begin{array}{l}4.581 \\
(7.003)\end{array}$ \\
\hline Has linking contact & $\begin{array}{l}.328 \\
(.469)\end{array}$ & $\begin{array}{l}.396 \\
(.489) \\
\end{array}$ & $\begin{array}{l}.415 \\
(.493)\end{array}$ & $\begin{array}{l}.351 \\
(.477) \\
\end{array}$ & $\begin{array}{l}.380 \\
(.486)\end{array}$ & $\begin{array}{l}.422 \\
(.494)\end{array}$ \\
\hline $\begin{array}{l}\text { Total contacts family and } \\
\text { friends }\end{array}$ & $\begin{array}{l}18.850 \\
(17.782)\end{array}$ & $\begin{array}{l}17.701 \\
(16.322)\end{array}$ & $\begin{array}{l}17.260 \\
(16.004)\end{array}$ & $\begin{array}{l}19.434 \\
(17.960)\end{array}$ & $\begin{array}{l}19.072 \\
(18.079)\end{array}$ & $\begin{array}{l}17.454 \\
(15.708)\end{array}$ \\
\hline $\begin{array}{l}\text { Total contacts can help find } \\
\text { jobs (bond+bridge) }\end{array}$ & $\begin{array}{l}27.565 \\
(28.505) \\
\end{array}$ & $\begin{array}{l}25.567 \\
(25.692) \\
\end{array}$ & $\begin{array}{l}24.727 \\
(24.107) \\
\end{array}$ & $\begin{array}{l}30.377 \\
(36.941) \\
\end{array}$ & $\begin{array}{l}27.154 \\
(28.458) \\
\end{array}$ & $\begin{array}{l}26.807 \\
(28.779) \\
\end{array}$ \\
\hline Gross hourly wage & $\begin{array}{l}12.811 \\
(6.914)\end{array}$ & $\begin{array}{l}13.933 \\
(7.813)\end{array}$ & $\begin{array}{l}16.037 \\
(19.967) \\
\end{array}$ & $\begin{array}{l}12.933 \\
(7.596)\end{array}$ & $\begin{array}{l}14.109 \\
(8.021)\end{array}$ & $\begin{array}{l}15.454 \\
(7.241)\end{array}$ \\
\hline $\begin{array}{l}\text { Usual working hours of the } \\
\text { main/last job }\end{array}$ & $\begin{array}{l}38.040 \\
(13.948)\end{array}$ & $\begin{array}{l}38.578 \\
(12.870)\end{array}$ & $\begin{array}{l}39.166 \\
(13.096) \\
\end{array}$ & $\begin{array}{l}41.149 \\
(14.723)\end{array}$ & $\begin{array}{l}40.833 \\
(13.814)\end{array}$ & $\begin{array}{l}41.099 \\
(14.153)\end{array}$ \\
\hline Estimated age of respondent & $\begin{array}{l}48.409 \\
(16.631)\end{array}$ & $\begin{array}{l}49.924 \\
(15.403)\end{array}$ & $\begin{array}{l}52.006 \\
(14.750)\end{array}$ & $\begin{array}{l}48.139 \\
(16.808)\end{array}$ & $\begin{array}{l}49.635 \\
(15.59)\end{array}$ & $\begin{array}{l}51.756 \\
(14.738)\end{array}$ \\
\hline Respondent is Males & $\begin{array}{l}.419 \\
(.493) \\
\end{array}$ & $\begin{array}{l}.406 \\
(.491) \\
\end{array}$ & $\begin{array}{l}.395 \\
(.489) \\
\end{array}$ & $\begin{array}{l}.418 \\
(.493) \\
\end{array}$ & $\begin{array}{l}.428 \\
(.495) \\
\end{array}$ & $\begin{array}{l}.411 \\
(.492) \\
\end{array}$ \\
\hline $\begin{array}{l}\text { Respondent passed high } \\
\text { school }\end{array}$ & $\begin{array}{l}.550 \\
(.498)\end{array}$ & $\begin{array}{l}.567 \\
(.496)\end{array}$ & $\begin{array}{l}.572 \\
(.495)\end{array}$ & $\begin{array}{l}.565 \\
(.496)\end{array}$ & $\begin{array}{l}.559 \\
(.497)\end{array}$ & $\begin{array}{l}.574 \\
(.495)\end{array}$ \\
\hline $\begin{array}{l}\text { Respondent has a bachelor's } \\
\text { degree }\end{array}$ & $\begin{array}{l}.083 \\
(.276) \\
\end{array}$ & $\begin{array}{l}.090 \\
(.286) \\
\end{array}$ & $\begin{array}{l}.095 \\
(.294) \\
\end{array}$ & $\begin{array}{l}.100 \\
(.300) \\
\end{array}$ & $\begin{array}{l}.117 \\
(.321) \\
\end{array}$ & $\begin{array}{l}.116 \\
(.32) \\
\end{array}$ \\
\hline $\begin{array}{l}\text { Respondent has some } \\
\text { university education }\end{array}$ & $\begin{array}{l}.024 \\
(.153) \\
\end{array}$ & $\begin{array}{l}.027 \\
(.163) \\
\end{array}$ & $\begin{array}{l}.030 \\
(.170) \\
\end{array}$ & $\begin{array}{l}.040 \\
(.197) \\
\end{array}$ & $\begin{array}{l}.041 \\
(.198) \\
\end{array}$ & $\begin{array}{l}.048 \\
(.213) \\
\end{array}$ \\
\hline Resides by themselves & $\begin{array}{l}.317 \\
(.465) \\
\end{array}$ & $\begin{array}{l}.285 \\
(.452) \\
\end{array}$ & $\begin{array}{l}.282 \\
(.45) \\
\end{array}$ & $\begin{array}{l}.321 \\
(.467) \\
\end{array}$ & $\begin{array}{l}.293 \\
(.455) \\
\end{array}$ & $\begin{array}{l}.276 \\
(.447) \\
\end{array}$ \\
\hline $\begin{array}{l}\text { Receiving pension in past } 12 \\
\text { months }\end{array}$ & $\begin{array}{l}.292 \\
(.455)\end{array}$ & $\begin{array}{l}.308 \\
(.462) \\
\end{array}$ & $\begin{array}{l}.341 \\
(.474) \\
\end{array}$ & $\begin{array}{l}.259 \\
(.438) \\
\end{array}$ & $\begin{array}{l}.264 \\
(.441) \\
\end{array}$ & $\begin{array}{l}.301 \\
(.459) \\
\end{array}$ \\
\hline $\begin{array}{l}\text { Receiving EI/SA in past } 12 \\
\text { months }\end{array}$ & $\begin{array}{l}.255 \\
(.436) \\
\end{array}$ & $\begin{array}{l}.253 \\
(.435)\end{array}$ & $\begin{array}{l}.237 \\
(.425)\end{array}$ & $\begin{array}{l}.280 \\
(.449)\end{array}$ & $\begin{array}{l}.276 \\
(.447)\end{array}$ & $\begin{array}{l}.255 \\
(.436)\end{array}$ \\
\hline Observations & 4395 & 3307 & 2736 & 3016 & 1952 & 1590 \\
\hline
\end{tabular}

Note: Standard Deviations in Parentheses. 
Table 3: Do Subsequent Attritors Differ in Their Initial Behavioural Relationships on Holding a Job?

\begin{tabular}{|c|c|c|c|c|}
\hline $\begin{array}{l}\text { Network variable } \\
\text { included in the } \\
\text { specification }\end{array}$ & $\begin{array}{l}\text { Number of } \\
\text { contacts that can } \\
\text { help find a job }\end{array}$ & $\begin{array}{l}\text { Number of contacts } \\
\text { - Acquaintances }\end{array}$ & $\begin{array}{l}\text { Number of contacts } \\
\text { that are friends and } \\
\text { family }\end{array}$ & $\begin{array}{l}\text { Number of contacts } \\
\text { in same community }\end{array}$ \\
\hline $\begin{array}{l}\text { Impact of the Network } \\
\text { variable }\end{array}$ & $\begin{array}{l}-0.001 \\
(0.003)\end{array}$ & $\begin{array}{c}-0.002 \\
(0.006)\end{array}$ & $\begin{array}{c}0.001 \\
(0.003)\end{array}$ & $\begin{array}{l}-0.002 \\
(0.003)\end{array}$ \\
\hline Age at baseline survey & $\begin{array}{c}0.014 \\
(0.012)\end{array}$ & $\begin{array}{c}0.014 \\
(0.012)\end{array}$ & $\begin{array}{c}0.014 \\
(0.012)\end{array}$ & $\begin{array}{c}0.012 \\
(0.012)\end{array}$ \\
\hline Age at baseline squared & $\begin{array}{l}-0.019 \\
(0.015) \\
\end{array}$ & $\begin{array}{l}-0.019 \\
(0.015)\end{array}$ & $\begin{array}{l}-0.020 \\
(0.015) \\
\end{array}$ & $\begin{array}{l}-0.017 \\
(0.015) \\
\end{array}$ \\
\hline Respondent is Male & $\begin{array}{c}-0.103 \\
(0.047)^{* *}\end{array}$ & $\begin{array}{c}-0.106 \\
(0.048)^{* *}\end{array}$ & $\begin{array}{c}-0.103 \\
(0.048)^{* *}\end{array}$ & $\begin{array}{c}-0.109 \\
(0.049) * *\end{array}$ \\
\hline $\begin{array}{l}\text { Respondent source of } \\
\text { sample is ei }\end{array}$ & $\begin{array}{c}0.059 \\
(0.044) \\
\end{array}$ & $\begin{array}{c}0.055 \\
(0.045)\end{array}$ & $\begin{array}{c}0.048 \\
(0.045) \\
\end{array}$ & $\begin{array}{c}0.054 \\
(0.045) \\
\end{array}$ \\
\hline $\begin{array}{l}\text { Respondent has high } \\
\text { school diploma }\end{array}$ & $\begin{array}{l}-0.017 \\
(0.029)\end{array}$ & $\begin{array}{l}-0.015 \\
(0.030)\end{array}$ & $\begin{array}{l}-0.021 \\
(0.029)\end{array}$ & $\begin{array}{l}-0.020 \\
(0.029)\end{array}$ \\
\hline $\begin{array}{l}\text { Respondent has college } \\
\text { diploma }\end{array}$ & $\begin{array}{c}0.064 \\
(0.073)\end{array}$ & $\begin{array}{c}0.066 \\
(0.074)\end{array}$ & $\begin{array}{l}0.060 \\
(0.074)\end{array}$ & $\begin{array}{c}0.064 \\
(0.074)\end{array}$ \\
\hline $\begin{array}{l}\text { Respondent: has a } \\
\text { university degree }\end{array}$ & $\begin{array}{c}-0.223 \\
(0.047)^{* * *}\end{array}$ & $\begin{array}{c}-0.220 \\
(0.049)^{* * *}\end{array}$ & $\begin{array}{c}-0.223 \\
(0.048)^{* * *}\end{array}$ & $\begin{array}{c}-0.221 \\
(0.047)^{* * *}\end{array}$ \\
\hline $\begin{array}{l}\text { Respondent has a } \\
\text { diploma }\end{array}$ & $\begin{array}{c}-0.081 \\
(0.045)^{*}\end{array}$ & $\begin{array}{c}-0.082 \\
(0.045)^{*}\end{array}$ & $\begin{array}{c}-0.084 \\
(0.046)^{*}\end{array}$ & $\begin{array}{c}-0.081 \\
(0.047)^{*}\end{array}$ \\
\hline Attrition Indicator & $\begin{array}{c}0.135 \\
(0.288) \\
\end{array}$ & $\begin{array}{c}0.113 \\
(0.289) \\
\end{array}$ & $\begin{array}{c}0.155 \\
(0.296) \\
\end{array}$ & $\begin{array}{c}0.112 \\
(0.296) \\
\end{array}$ \\
\hline $\begin{array}{l}\text { Attrition * Age at } \\
\text { baseline survey }\end{array}$ & $\begin{array}{l}-0.008 \\
(0.014)\end{array}$ & $\begin{array}{l}-0.007 \\
(0.015)\end{array}$ & $\begin{array}{l}-0.008 \\
(0.015)\end{array}$ & $\begin{array}{l}-0.007 \\
(0.015)\end{array}$ \\
\hline $\begin{array}{l}\text { Attrition * Age at } \\
\text { baseline squared }\end{array}$ & $\begin{array}{c}0.009 \\
(0.018) \\
\end{array}$ & $\begin{array}{c}0.008 \\
(0.018) \\
\end{array}$ & $\begin{array}{c}0.010 \\
(0.018) \\
\end{array}$ & $\begin{array}{c}0.008 \\
(0.018) \\
\end{array}$ \\
\hline $\begin{array}{l}\text { Attrition * Respondent } \\
\text { is Male }\end{array}$ & $\begin{array}{l}-0.042 \\
(0.054) \\
\end{array}$ & $\begin{array}{l}-0.034 \\
(0.054)\end{array}$ & $\begin{array}{l}-0.048 \\
(0.055) \\
\end{array}$ & $\begin{array}{l}-0.036 \\
(0.055) \\
\end{array}$ \\
\hline $\begin{array}{l}\text { Attrition * Resp. } \\
\text { source of sample is ei }\end{array}$ & $\begin{array}{l}-0.035 \\
(0.081) \\
\end{array}$ & $\begin{array}{l}-0.037 \\
(0.082) \\
\end{array}$ & $\begin{array}{l}-0.031 \\
(0.082) \\
\end{array}$ & $\begin{array}{l}-0.033 \\
(0.081) \\
\end{array}$ \\
\hline $\begin{array}{l}\text { Attrition * Resp. has } \\
\text { high school diploma }\end{array}$ & $\begin{array}{c}0.066 \\
(0.049)\end{array}$ & $\begin{array}{c}0.063 \\
(0.050)\end{array}$ & $\begin{array}{c}0.073 \\
(0.050)\end{array}$ & $\begin{array}{c}0.068 \\
(0.051)\end{array}$ \\
\hline $\begin{array}{l}\text { Attrition * Resp. has } \\
\text { college diploma }\end{array}$ & $\begin{array}{c}0.199 \\
(0.078)^{* *}\end{array}$ & $\begin{array}{c}0.195 \\
(0.079)^{* *}\end{array}$ & $\begin{array}{c}0.201 \\
(0.080)^{* *}\end{array}$ & $\begin{array}{c}0.198 \\
(0.078)^{* *}\end{array}$ \\
\hline $\begin{array}{l}\text { Attrition * has a } \\
\text { university degree }\end{array}$ & $\begin{array}{l}-0.005 \\
(0.064)\end{array}$ & $\begin{array}{l}-0.002 \\
(0.065)\end{array}$ & $\begin{array}{l}-0.003 \\
(0.065) \\
\end{array}$ & $\begin{array}{l}-0.007 \\
(0.064)\end{array}$ \\
\hline $\begin{array}{l}\text { Attrition * Resp. has a } \\
\text { diploma }\end{array}$ & $\begin{array}{c}-0.133 \\
(0.070)^{*}\end{array}$ & $\begin{array}{c}-0.132 \\
(0.070)^{*}\end{array}$ & $\begin{array}{c}-0.131 \\
(0.071)^{*}\end{array}$ & $\begin{array}{c}-0.126 \\
(0.071)^{*}\end{array}$ \\
\hline $\begin{array}{l}\text { Attrition * network } \\
\text { variable }\end{array}$ & $\begin{array}{c}0.001 \\
(0.003)\end{array}$ & $\begin{array}{c}0.007 \\
(0.007)\end{array}$ & $\begin{array}{l}-0.002 \\
(0.003)\end{array}$ & $\begin{array}{c}0.002 \\
(0.003)\end{array}$ \\
\hline $\begin{array}{l}\text { F-Test for selective } \\
\text { attrition }\end{array}$ & $\begin{array}{c}1.51 \\
{[0.114]}\end{array}$ & $\begin{array}{c}1.53 \\
{[0.108]}\end{array}$ & $\begin{array}{c}1.48 \\
{[0.124]}\end{array}$ & $\begin{array}{c}1.58 \\
{[0.091]}\end{array}$ \\
\hline Observations & 1433 & 1403 & 1404 & 1424 \\
\hline R-squared & 0.05 & 0.05 & 0.05 & 0.05 \\
\hline
\end{tabular}

Note: Robust standard errors in parentheses and Prob $>$ F in []. Specification also include household structure, family income and interactions with the attrition indicator. ${ }^{* * *}, * *$ and ${ }^{*}$ respectively denote statistically different from zero at the $1 \%, 5 \%$ and $10 \%$ confidence levels. 
Table 4: Instrumental Variables of Factors Explaining Holding a Job 18 Months Post Experiment

\begin{tabular}{|c|c|c|c|c|}
\hline $\begin{array}{l}\text { Specification-> } \\
\text { Explanatory variable } \downarrow\end{array}$ & 1 & 2 & 3 & 4 \\
\hline $\begin{array}{l}\text { Change in number of contacts that can } \\
\text { help find a job }\end{array}$ & $\begin{array}{l}-0.019 \\
(0.029)\end{array}$ & & & \\
\hline $\begin{array}{l}\text { Change in number of contacts - } \\
\text { Acquaintances }\end{array}$ & & $\begin{array}{l}-0.015 \\
(0.040)\end{array}$ & & \\
\hline $\begin{array}{l}\text { Change in number of contacts that are } \\
\text { friends and family }\end{array}$ & & & $\begin{array}{l}-0.063 \\
(0.223)\end{array}$ & \\
\hline $\begin{array}{l}\text { Change in number of contacts in same } \\
\text { community }\end{array}$ & & & & $\begin{array}{c}0.042 \\
(0.164)\end{array}$ \\
\hline Age at baseline survey & $\begin{array}{c}0.038 \\
(0.012)^{* * *}\end{array}$ & $\begin{array}{c}0.040 \\
(0.011)^{* * *}\end{array}$ & $\begin{array}{c}0.051 \\
(0.030)^{*}\end{array}$ & $\begin{array}{c}0.035 \\
(0.031)\end{array}$ \\
\hline Age at baseline squared & $\begin{array}{c}-0.065 \\
(0.016) * * *\end{array}$ & $\begin{array}{c}-0.065 \\
(0.014)^{* * *}\end{array}$ & $\begin{array}{l}-0.086 \\
(0.066)\end{array}$ & $\begin{array}{l}-0.055 \\
(0.051)\end{array}$ \\
\hline Respondent is Male & $\begin{array}{c}0.057 \\
(0.060)\end{array}$ & $\begin{array}{c}0.023 \\
(0.036)\end{array}$ & $\begin{array}{c}0.104 \\
(0.290)\end{array}$ & $\begin{array}{l}-0.035 \\
(0.234)\end{array}$ \\
\hline Respondent source of sample is ei & $\begin{array}{c}0.207 \\
(0.052) * * *\end{array}$ & $\begin{array}{c}0.165 \\
(0.075)^{* *}\end{array}$ & $\begin{array}{c}0.169 \\
(0.106)\end{array}$ & $\begin{array}{c}0.142 \\
(0.181)\end{array}$ \\
\hline Respondent has high school diploma & $\begin{array}{c}-0.118 \\
(0.066)^{*}\end{array}$ & $\begin{array}{c}-0.110 \\
(0.048)^{* *}\end{array}$ & $\begin{array}{l}-0.165 \\
(0.249)\end{array}$ & $\begin{array}{l}-0.103 \\
(0.092)\end{array}$ \\
\hline Respondent has college diploma & $\begin{array}{l}-0.002 \\
(0.080)\end{array}$ & $\begin{array}{c}0.023 \\
(0.055)\end{array}$ & $\begin{array}{l}-0.053 \\
(0.353)\end{array}$ & $\begin{array}{c}0.068 \\
(0.124)\end{array}$ \\
\hline Respondent: has a university degree & $\begin{array}{c}0.151 \\
(0.087)^{*}\end{array}$ & $\begin{array}{c}0.123 \\
(0.081)\end{array}$ & $\begin{array}{c}0.009 \\
(0.459)\end{array}$ & $\begin{array}{c}0.029 \\
(0.439)\end{array}$ \\
\hline Respondent has a diploma & $\begin{array}{c}-0.062 \\
(0.078)\end{array}$ & $\begin{array}{l}-0.045 \\
(0.052)\end{array}$ & $\begin{array}{l}-0.092 \\
(0.265)\end{array}$ & $\begin{array}{c}0.006 \\
(0.116)\end{array}$ \\
\hline Single & $\begin{array}{l}-0.047 \\
(0.086)\end{array}$ & $\begin{array}{l}-0.019 \\
(0.052)\end{array}$ & $\begin{array}{l}-0.069 \\
(0.278)\end{array}$ & $\begin{array}{c}0.002 \\
(0.071)\end{array}$ \\
\hline Divorced & $\begin{array}{c}0.045 \\
(0.056)\end{array}$ & $\begin{array}{c}0.023 \\
(0.051)\end{array}$ & $\begin{array}{c}-0.052 \\
(0.256)\end{array}$ & $\begin{array}{c}0.032 \\
(0.071)\end{array}$ \\
\hline Does Not have children & $\begin{array}{c}0.036 \\
(0.042)\end{array}$ & $\begin{array}{c}0.020 \\
(0.048)\end{array}$ & $\begin{array}{c}0.061 \\
(0.095)\end{array}$ & $\begin{array}{c}0.056 \\
(0.072)\end{array}$ \\
\hline Constant & $\begin{array}{c}0.016 \\
(0.359)\end{array}$ & $\begin{array}{c}-0.099 \\
(0.273)\end{array}$ & $\begin{array}{c}0.019 \\
(1.027)\end{array}$ & $\begin{array}{c}-0.185 \\
(0.336)\end{array}$ \\
\hline Observations & 987 & 963 & 971 & 983 \\
\hline
\end{tabular}

Note: Robust standard errors in parentheses. Specification also include indicators for household structure and family income. ${ }^{* * *}, * *$ and $*$ respectively denote statistically different from zero at the $1 \%, 5 \%$ and $10 \%$ confidence levels. 
Table 5 OLS Estimates of Factors Explaining Having a Job 18 Months Following the CEIP Experiment

\begin{tabular}{|c|c|c|c|c|}
\hline $\begin{array}{l}\text { Specification-> } \\
\text { Explanatory variable } \downarrow\end{array}$ & 1 & 2 & 3 & 4 \\
\hline $\begin{array}{l}\text { Change in number of } \\
\text { contacts that can help find a } \\
\text { job }\end{array}$ & $\begin{array}{c}0.0023 \\
(0.0012)^{*}\end{array}$ & & & \\
\hline $\begin{array}{l}\text { Change in number of } \\
\text { contacts - Acquaintances }\end{array}$ & & $\begin{array}{c}0.0010 \\
(0.0025) \\
\end{array}$ & & \\
\hline $\begin{array}{l}\text { Change in number of } \\
\text { contacts that are friends and } \\
\text { family }\end{array}$ & & & $\begin{array}{c}0.0008 \\
(0.0014)\end{array}$ & \\
\hline $\begin{array}{l}\text { Change in number of } \\
\text { contacts in same community }\end{array}$ & & & & $\begin{array}{l}0.0010 \\
(0.0011)\end{array}$ \\
\hline Age at baseline survey & $\begin{array}{c}0.037 \\
(0.010)^{* * *}\end{array}$ & $\begin{array}{c}0.040 \\
(0.011)^{* * *}\end{array}$ & $\begin{array}{c}0.043 \\
(0.011)^{* * *}\end{array}$ & $\begin{array}{c}0.042 \\
(0.010)^{* * *}\end{array}$ \\
\hline Age at baseline squared & $\begin{array}{c}-0.060 \\
(0.013)^{* * *}\end{array}$ & $\begin{array}{c}-0.065 \\
(0.013)^{* * *}\end{array}$ & $\begin{array}{c}-0.068 \\
(0.013) * * *\end{array}$ & $\begin{array}{c}-0.066 \\
(0.013)^{* * *}\end{array}$ \\
\hline Respondent is Male & $\begin{array}{c}0.028 \\
(0.034)\end{array}$ & $\begin{array}{c}0.022 \\
(0.035)\end{array}$ & $\begin{array}{c}0.026 \\
(0.035)\end{array}$ & $\begin{array}{c}0.020 \\
(0.034)\end{array}$ \\
\hline $\begin{array}{l}\text { Respondent source of } \\
\text { sample is ei }\end{array}$ & $\begin{array}{c}0.195 \\
(0.043)^{* * *}\end{array}$ & $\begin{array}{c}0.189 \\
(0.044)^{* * *}\end{array}$ & $\begin{array}{c}0.182 \\
(0.044)^{* * *}\end{array}$ & $\begin{array}{c}0.184 \\
(0.044)^{* * *}\end{array}$ \\
\hline $\begin{array}{l}\text { Respondent has high school } \\
\text { diploma }\end{array}$ & $\begin{array}{c}-0.090 \\
(0.043)^{* *}\end{array}$ & $\begin{array}{c}-0.104 \\
(0.044)^{* *}\end{array}$ & $\begin{array}{c}-0.104 \\
(0.044)^{* *}\end{array}$ & $\begin{array}{c}-0.088 \\
(0.044)^{* *}\end{array}$ \\
\hline $\begin{array}{l}\text { Respondent has college } \\
\text { diploma }\end{array}$ & $\begin{array}{c}0.040 \\
(0.050)\end{array}$ & $\begin{array}{c}0.031 \\
(0.050)\end{array}$ & $\begin{array}{c}0.041 \\
(0.051)\end{array}$ & $\begin{array}{c}0.045 \\
(0.050)\end{array}$ \\
\hline $\begin{array}{l}\text { Respondent: has a university } \\
\text { degree }\end{array}$ & $\begin{array}{c}0.131 \\
(0.076)^{*}\end{array}$ & $\begin{array}{c}0.125 \\
(0.075)^{*}\end{array}$ & $\begin{array}{c}0.135 \\
(0.076)^{*}\end{array}$ & $\begin{array}{c}0.135 \\
(0.075)^{*}\end{array}$ \\
\hline Respondent has a diploma & $\begin{array}{l}-0.022 \\
(0.042)\end{array}$ & $\begin{array}{l}-0.034 \\
(0.043)\end{array}$ & $\begin{array}{l}-0.026 \\
(0.043)\end{array}$ & $\begin{array}{l}-0.016 \\
(0.042)\end{array}$ \\
\hline Single & $\begin{array}{l}-0.005 \\
(0.045)\end{array}$ & $\begin{array}{l}-0.013 \\
(0.047)\end{array}$ & $\begin{array}{c}-0.002 \\
(0.046)\end{array}$ & $\begin{array}{c}0.005 \\
(0.046)\end{array}$ \\
\hline Divorced & $\begin{array}{c}0.025 \\
(0.046)\end{array}$ & $\begin{array}{c}0.014 \\
(0.046)\end{array}$ & $\begin{array}{c}0.012 \\
(0.047)\end{array}$ & $\begin{array}{c}0.031 \\
(0.046)\end{array}$ \\
\hline Does not have children & $\begin{array}{c}0.046 \\
(0.035)\end{array}$ & $\begin{array}{c}0.033 \\
(0.036)\end{array}$ & $\begin{array}{c}0.038 \\
(0.035)\end{array}$ & $\begin{array}{c}0.045 \\
(0.035)\end{array}$ \\
\hline Constant & $\begin{array}{l}-0.144 \\
(0.213)\end{array}$ & $\begin{array}{c}-0.153 \\
(0.216)\end{array}$ & $\begin{array}{c}-0.221 \\
(0.217)\end{array}$ & $\begin{array}{l}-0.207 \\
(0.213)\end{array}$ \\
\hline Observations & 987 & 963 & 971 & 983 \\
\hline R-squared & 0.11 & 0.11 & 0.11 & 0.11 \\
\hline
\end{tabular}

Note: Robust standard errors in parentheses. Specification also include indicators for household structure and family income. ${ }^{* * *}, * *$ and $*$ respectively denote statistically different from zero at the $1 \%, 5 \%$ and $10 \%$ confidence levels. 
Table 6: Estimates from the First Stage Regression Explaining Changes in the Size of Social Network Variables during the course of the Experiment

\begin{tabular}{|c|c|c|c|c|}
\hline $\begin{array}{l}\text { Dependent } \\
\text { variable in the first } \\
\text { stage equation }\end{array}$ & $\begin{array}{l}\text { Change in the } \\
\text { number of } \\
\text { contacts that can } \\
\text { help find a job }\end{array}$ & $\begin{array}{l}\text { Change in the } \\
\text { number of } \\
\text { contacts - } \\
\text { Acquaintances }\end{array}$ & $\begin{array}{l}\text { Change in the } \\
\text { number of } \\
\text { contacts that are } \\
\text { friends and family }\end{array}$ & $\begin{array}{l}\text { Change in the } \\
\text { number of } \\
\text { contacts in same } \\
\text { community as } \\
\text { respondent }\end{array}$ \\
\hline $\begin{array}{l}\text { Assigned to CEIP } \\
\text { treatment }\end{array}$ & $\begin{array}{c}1.704 \\
(0.740)^{* *}\end{array}$ & $\begin{array}{c}0.854 \\
(0.412)^{* *}\end{array}$ & $\begin{array}{c}0.111 \\
(0.709)\end{array}$ & $\begin{array}{l}-0.203 \\
(0.764)\end{array}$ \\
\hline $\begin{array}{l}\text { Age at baseline } \\
\text { survey }\end{array}$ & $\begin{array}{c}0.234 \\
(0.241) \\
\end{array}$ & $\begin{array}{c}0.057 \\
(0.163) \\
\end{array}$ & $\begin{array}{c}0.151 \\
(0.238) \\
\end{array}$ & $\begin{array}{c}0.229 \\
(0.269) \\
\end{array}$ \\
\hline $\begin{array}{l}\text { Age at baseline } \\
\text { squared }\end{array}$ & $\begin{array}{c}-0.453 \\
(0.275)^{*}\end{array}$ & $\begin{array}{l}-0.115 \\
(0.200)\end{array}$ & $\begin{array}{l}-0.319 \\
(0.285)\end{array}$ & $\begin{array}{l}-0.364 \\
(0.342)\end{array}$ \\
\hline $\begin{array}{l}\text { Respondent is } \\
\text { Male }\end{array}$ & $\begin{array}{c}0.822 \\
(0.898) \\
\end{array}$ & $\begin{array}{c}-0.091 \\
(0.533) \\
\end{array}$ & $\begin{array}{c}1.334 \\
(0.861) \\
\end{array}$ & $\begin{array}{c}1.709 \\
(0.930)^{*}\end{array}$ \\
\hline $\begin{array}{l}\text { Respondent } \\
\text { source of sample is } \\
\text { ei }\end{array}$ & $\begin{array}{l}-1.776 \\
(1.157)\end{array}$ & $\begin{array}{c}-1.688 \\
(0.637)^{* * *}\end{array}$ & $\begin{array}{c}0.245 \\
(1.111)\end{array}$ & $\begin{array}{c}1.138 \\
(1.138)\end{array}$ \\
\hline $\begin{array}{l}\text { Respondent has } \\
\text { high school } \\
\text { diploma }\end{array}$ & $\begin{array}{c}0.921 \\
(2.521)\end{array}$ & $\begin{array}{l}-0.093 \\
(0.651)\end{array}$ & $\begin{array}{l}-0.494 \\
(1.104)\end{array}$ & $\begin{array}{c}0.656 \\
(1.215)\end{array}$ \\
\hline $\begin{array}{l}\text { Respondent has } \\
\text { college diploma }\end{array}$ & $\begin{array}{c}-1.861 \\
(1.129) *\end{array}$ & $\begin{array}{l}-0.400 \\
(0.670)\end{array}$ & $\begin{array}{l}-1.800 \\
(1.151)\end{array}$ & $\begin{array}{l}-0.962 \\
(1.282)\end{array}$ \\
\hline $\begin{array}{l}\text { Respondent: has a } \\
\text { university degree }\end{array}$ & $\begin{array}{l}-1.685 \\
(1.389)\end{array}$ & $\begin{array}{c}0.198 \\
(1.434)\end{array}$ & $\begin{array}{l}-1.787 \\
(1.475)\end{array}$ & $\begin{array}{c}2.193 \\
(1.645)\end{array}$ \\
\hline $\begin{array}{l}\text { Respondent has a } \\
\text { diploma }\end{array}$ & $\begin{array}{c}0.652 \\
(1.004)\end{array}$ & $\begin{array}{l}-0.628 \\
(0.640)\end{array}$ & $\begin{array}{l}-1.218 \\
(1.091)\end{array}$ & $\begin{array}{l}-0.788 \\
(1.215)\end{array}$ \\
\hline Single & $\begin{array}{l}-0.856 \\
(0.707) \\
\end{array}$ & $\begin{array}{l}-0.332 \\
(0.769) \\
\end{array}$ & $\begin{array}{l}-1.017 \\
(1.239)\end{array}$ & $\begin{array}{c}0.057 \\
(1.156)\end{array}$ \\
\hline Divorced & $\begin{array}{c}1.150 \\
(1.102) \\
\end{array}$ & $\begin{array}{c}0.372 \\
(0.757) \\
\end{array}$ & $\begin{array}{l}-0.916 \\
(1.104)\end{array}$ & $\begin{array}{c}0.354 \\
(1.199)\end{array}$ \\
\hline $\begin{array}{l}\text { Does not have } \\
\text { children }\end{array}$ & $\begin{array}{c}0.626 \\
(1.085)\end{array}$ & $\begin{array}{c}-0.829 \\
(0.395)^{* *}\end{array}$ & $\begin{array}{c}0.009 \\
(0.765)\end{array}$ & $\begin{array}{l}-0.655 \\
(0.966)\end{array}$ \\
\hline Constant & $\begin{array}{r}2.280 \\
(6.049) \\
\end{array}$ & $\begin{array}{c}1.438 \\
(3.655) \\
\end{array}$ & $\begin{array}{c}2.767 \\
(5.287) \\
\end{array}$ & $\begin{array}{c}-1.808 \\
(5.202) \\
\end{array}$ \\
\hline R-squared & 0.02 & 0.04 & 0.02 & 0.02 \\
\hline
\end{tabular}

Note: Robust standard errors in parentheses. Specification also include indicators for household structure and family income. ${ }^{* * *}, * *$ and $*$ respectively denote statistically different from zero at the $1 \%, 5 \%$ and $10 \%$ confidence levels. 
Table 7: IV and OLS Estimates Explaining Holding a Job 18 Months Post Experiment on Subsamples

\begin{tabular}{|c|c|c|c|c|}
\hline Subsamples-> & \multicolumn{2}{|c|}{ FEMALES ONLY } & \multicolumn{2}{|c|}{ DIPLOMA HOLDERS ONLY } \\
\hline \multicolumn{5}{|c|}{ INSTRUMENTAL VARIALES ESTIMATES } \\
\hline $\begin{array}{l}\text { Change in number of contacts that } \\
\text { can help find a job }\end{array}$ & $\begin{array}{l}-0.001 \\
(0.015)\end{array}$ & & $\begin{array}{l}-0.021 \\
(0.015)\end{array}$ & \\
\hline $\begin{array}{l}\text { Change in number of contacts - } \\
\text { Acquaintances }\end{array}$ & & $\begin{array}{c}0.002 \\
(0.028)\end{array}$ & & $\begin{array}{l}-0.027 \\
(0.024)\end{array}$ \\
\hline Age at baseline survey & $\begin{array}{c}0.057 \\
(0.015)^{* * *}\end{array}$ & $\begin{array}{c}0.040 \\
(0.011)^{* * *}\end{array}$ & $\begin{array}{c}0.043 \\
(0.017)^{* * *}\end{array}$ & $\begin{array}{c}0.056 \\
(0.020)^{* * *}\end{array}$ \\
\hline Age at baseline squared & $\begin{array}{c}-0.085 \\
(0.020)^{* * *}\end{array}$ & $\begin{array}{c}-0.065 \\
(0.014)^{* * *}\end{array}$ & $\begin{array}{c}-0.075 \\
(0.021)^{* * *}\end{array}$ & $\begin{array}{c}-0.091 \\
(0.024)^{* * *}\end{array}$ \\
\hline Respondent is Male & N/A & $\mathrm{N} / \mathrm{A}$ & $\begin{array}{c}0.018 \\
(0.053)\end{array}$ & $\begin{array}{l}-0.020 \\
(0.054)\end{array}$ \\
\hline Respondent source of sample is ei & $\begin{array}{c}0.208 \\
(0.069)^{* * *}\end{array}$ & $\begin{array}{c}0.187 \\
(0.058)^{* * *}\end{array}$ & $\begin{array}{c}0.134 \\
(0.072)^{*}\end{array}$ & $\begin{array}{c}0.105 \\
(0.069)\end{array}$ \\
\hline Respondent has high school diploma & $\begin{array}{c}-0.133 \\
(0.057)^{* *}\end{array}$ & $\begin{array}{c}-0.127 \\
(0.060)^{* *}\end{array}$ & $\mathrm{~N} / \mathrm{A}$ & N/A \\
\hline Respondent has college diploma & $\begin{array}{l}-0.031 \\
(0.067) \\
\end{array}$ & $\begin{array}{l}-0.020 \\
(0.068) \\
\end{array}$ & $\mathrm{N} / \mathrm{A}$ & $\mathrm{N} / \mathrm{A}$ \\
\hline Respondent: has a university degree & $\begin{array}{c}0.126 \\
(0.089) \\
\end{array}$ & $\begin{array}{c}0.132 \\
(0.090)\end{array}$ & $\mathrm{N} / \mathrm{A}$ & $\mathrm{N} / \mathrm{A}$ \\
\hline Respondent has a diploma & $\begin{array}{l}-0.024 \\
(0.063)\end{array}$ & $\begin{array}{l}-0.009 \\
(0.065)\end{array}$ & $\mathrm{N} / \mathrm{A}$ & $\mathrm{N} / \mathrm{A}$ \\
\hline \multicolumn{5}{|c|}{ ORDINARY LEAST SQUARES ESTIMATES } \\
\hline $\begin{array}{l}\text { Change in number of contacts that } \\
\text { can help find a job }\end{array}$ & $\begin{array}{c}0.004 \\
(0.002)^{* *}\end{array}$ & & $\begin{array}{c}0.001 \\
(0.002)\end{array}$ & \\
\hline $\begin{array}{l}\text { Change in number of contacts - } \\
\text { Acquaintances }\end{array}$ & & $\begin{array}{c}0.0068 \\
(0.004)^{*}\end{array}$ & & $\begin{array}{l}-0.001 \\
(0.004)\end{array}$ \\
\hline Age at baseline survey & $\begin{array}{c}0.055 \\
(0.015)^{* * *}\end{array}$ & $\begin{array}{c}0.058 \\
(0.015)^{* * *}\end{array}$ & $\begin{array}{c}0.040 \\
(0.016)^{* *}\end{array}$ & $\begin{array}{c}0.044 \\
(0.016)^{* * *}\end{array}$ \\
\hline Age at baseline squared & $\begin{array}{c}-0.083 \\
(0.019)^{* * *}\end{array}$ & $\begin{array}{c}-0.087 \\
(0.019)^{* * *}\end{array}$ & $\begin{array}{c}-0.070 \\
(0.019)^{* * *}\end{array}$ & $\begin{array}{c}-0.075 \\
(0.019)^{* * *}\end{array}$ \\
\hline Respondent is Male & & & $\begin{array}{c}0.029 \\
(0.050)\end{array}$ & $\begin{array}{c}0.005 \\
(0.051)\end{array}$ \\
\hline Respondent source of sample is ei & $\begin{array}{c}0.196 \\
(0.057)^{* * *}\end{array}$ & $\begin{array}{c}0.189 \\
(0.058)^{* * *}\end{array}$ & $\begin{array}{c}0.115 \\
(0.065)^{*}\end{array}$ & $\begin{array}{c}0.122 \\
(0.065)^{*}\end{array}$ \\
\hline Respondent has high school diploma & $\begin{array}{c}-0.133 \\
(0.057)^{* *}\end{array}$ & $\begin{array}{c}-0.130 \\
(0.058)^{* *}\end{array}$ & $\mathrm{~N} / \mathrm{A}$ & $\mathrm{N} / \mathrm{A}$ \\
\hline Respondent has college diploma & $\begin{array}{l}-0.029 \\
(0.068)\end{array}$ & $\begin{array}{l}-0.022 \\
(0.069)\end{array}$ & N/A & N/A \\
\hline Respondent: has a university degree & $\begin{array}{c}0.121 \\
(0.091)\end{array}$ & $\begin{array}{c}0.129 \\
(0.090)\end{array}$ & N/A & $\mathrm{N} / \mathrm{A}$ \\
\hline Respondent has a diploma & $\begin{array}{l}-0.026 \\
(0.064)\end{array}$ & $\begin{array}{l}-0.011 \\
(0.065)\end{array}$ & $\mathrm{N} / \mathrm{A}$ & $\mathrm{N} / \mathrm{A}$ \\
\hline Observation & 519 & 513 & 489 & 478 \\
\hline
\end{tabular}

Note: Robust standard errors in parentheses. Specification also the same covariates as in tables 3 and 4. *** $* *$ and $*$ respectively denote statistically different from 0 at the $1 \%, 5 \%$ and $10 \%$ confidence levels. 
Table 8: OLS Estimates of the Reduced Form Model of Holding a Job 18 Months Post CEIP Experiment

\begin{tabular}{|c|c|c|c|c|c|c|c|c|c|}
\hline Sample & Full Sample & $\begin{array}{l}\text { Females } \\
\text { Only }\end{array}$ & Males Only & $\begin{array}{l}\text { Low } \\
\text { Education }\end{array}$ & $\begin{array}{l}\text { Have a } \\
\text { Diploma }\end{array}$ & $\begin{array}{l}\text { Change in } \\
\text { Number of } \\
\text { Contacts } \\
\text { who Help } \\
\text { with Jobs }\end{array}$ & $\begin{array}{l}\text { Change in } \\
\text { Number of } \\
\text { Contacts } \\
\text { Acquaintance }\end{array}$ & $\begin{array}{l}\text { Change in } \\
\text { Number of } \\
\text { Contacts } \\
\text { Family and } \\
\text { Friends }\end{array}$ & $\begin{array}{l}\text { Change in } \\
\text { Number of } \\
\text { Contacts } \\
\text { Same } \\
\text { Community }\end{array}$ \\
\hline Program participant & $\begin{array}{l}-0.031 \\
(0.029)\end{array}$ & $\begin{array}{l}-0.028 \\
(0.039) \\
\end{array}$ & $\begin{array}{r}-0.047 \\
(0.043)\end{array}$ & $\begin{array}{c}0.012 \\
(0.041)\end{array}$ & $\begin{array}{c}-0.073 \\
(0.041)^{*}\end{array}$ & $\begin{array}{l}-0.032 \\
(0.035)\end{array}$ & $\begin{array}{l}-0.040 \\
(0.049)\end{array}$ & $\begin{array}{c}-0.069 \\
(0.037)^{*}\end{array}$ & $\begin{array}{l}-0.045 \\
(0.037) \\
\end{array}$ \\
\hline Age of respondent & $\begin{array}{c}0.036 \\
(0.010)^{* * *}\end{array}$ & $\begin{array}{c}0.062 \\
(0.014)^{* * *}\end{array}$ & $\begin{array}{c}0.013 \\
(0.014)\end{array}$ & $\begin{array}{c}0.034 \\
(0.014)^{* *}\end{array}$ & $\begin{array}{c}0.030 \\
(0.015)^{* *}\end{array}$ & $\begin{array}{c}0.032 \\
(0.012)^{* * *}\end{array}$ & $\begin{array}{c}0.013 \\
(0.018)\end{array}$ & $\begin{array}{c}0.036 \\
(0.013)^{* * *}\end{array}$ & $\begin{array}{c}0.032 \\
(0.013)^{* *}\end{array}$ \\
\hline Age at baseline squared & $\begin{array}{c}-0.058 \\
(0.012)^{* * *}\end{array}$ & $\begin{array}{c}-0.091 \\
(0.017)^{* * *}\end{array}$ & $\begin{array}{c}-0.029 \\
(0.018)^{*}\end{array}$ & $\begin{array}{c}-0.052 \\
(0.017)^{* * *}\end{array}$ & $\begin{array}{c}-0.056 \\
(0.018)^{* * *}\end{array}$ & $\begin{array}{c}-0.054 \\
(0.015)^{* * *}\end{array}$ & $\begin{array}{l}-0.033 \\
(0.022)\end{array}$ & $\begin{array}{c}-0.055 \\
(0.016)^{* * *}\end{array}$ & $\begin{array}{c}-0.050 \\
(0.016)^{* * *}\end{array}$ \\
\hline Male & $\begin{array}{c}0.024 \\
(0.032)\end{array}$ & & & $\begin{array}{c}0.031 \\
(0.044)\end{array}$ & $\begin{array}{c}0.018 \\
(0.046)\end{array}$ & $\begin{array}{c}0.002 \\
(0.037)\end{array}$ & $\begin{array}{l}-0.034 \\
(0.053)\end{array}$ & $\begin{array}{c}0.014 \\
(0.040)\end{array}$ & $\begin{array}{c}0.005 \\
(0.040)\end{array}$ \\
\hline Source of sample is ei & $\begin{array}{c}0.161 \\
(0.041)^{* * *}\end{array}$ & $\begin{array}{c}0.151 \\
(0.054)^{* * *}\end{array}$ & $\begin{array}{c}0.151 \\
(0.063)^{* *}\end{array}$ & $\begin{array}{c}0.216 \\
(0.056)^{* * *}\end{array}$ & $\begin{array}{c}0.094 \\
(0.060)\end{array}$ & $\begin{array}{c}0.130 \\
(0.050)^{* * *}\end{array}$ & $\begin{array}{c}0.110 \\
(0.068)\end{array}$ & $\begin{array}{c}0.155 \\
(0.052)^{* * *}\end{array}$ & $\begin{array}{c}0.157 \\
(0.053)^{* * *}\end{array}$ \\
\hline $\begin{array}{l}\text { Respondent has high } \\
\text { school diploma }\end{array}$ & $\begin{array}{c}-0.095 \\
(0.041)^{* *}\end{array}$ & $\begin{array}{c}-0.136 \\
(0.055)^{* *}\end{array}$ & $\begin{array}{l}-0.046 \\
(0.065)\end{array}$ & $\begin{array}{c}-0.090 \\
(0.043)^{* *}\end{array}$ & & $\begin{array}{l}-0.070 \\
(0.050)\end{array}$ & $\begin{array}{l}-0.028 \\
(0.070)\end{array}$ & $\begin{array}{l}-0.069 \\
(0.054)\end{array}$ & $\begin{array}{c}-0.092 \\
(0.053)^{*}\end{array}$ \\
\hline $\begin{array}{l}\text { Respondent has college } \\
\text { diploma }\end{array}$ & $\begin{array}{c}0.040 \\
(0.050)\end{array}$ & $\begin{array}{l}-0.006 \\
(0.064)\end{array}$ & $\begin{array}{c}0.093 \\
(0.083)\end{array}$ & & $\begin{array}{l}-0.067 \\
(0.079)\end{array}$ & $\begin{array}{c}0.055 \\
(0.058)\end{array}$ & $\begin{array}{c}0.155 \\
(0.088)^{*}\end{array}$ & $\begin{array}{c}0.037 \\
(0.062)\end{array}$ & $\begin{array}{c}0.019 \\
(0.062)\end{array}$ \\
\hline $\begin{array}{l}\text { Respondent has a } \\
\text { university degree }\end{array}$ & $\begin{array}{c}0.101 \\
(0.076)\end{array}$ & $\begin{array}{c}0.119 \\
(0.085)\end{array}$ & $\begin{array}{l}-0.066 \\
(0.177)\end{array}$ & & & $\begin{array}{c}0.078 \\
(0.094)\end{array}$ & $\begin{array}{c}0.168 \\
(0.118)\end{array}$ & $\begin{array}{c}0.058 \\
(0.106)\end{array}$ & $\begin{array}{c}0.071 \\
(0.097)\end{array}$ \\
\hline $\begin{array}{l}\text { Respondent has a a } \\
\text { diploma }\end{array}$ & $\begin{array}{l}-0.025 \\
(0.039) \\
\end{array}$ & $\begin{array}{l}-0.024 \\
(0.059)\end{array}$ & $\begin{array}{l}-0.005 \\
(0.054)\end{array}$ & & $\begin{array}{l}-0.121 \\
(0.076)\end{array}$ & $\begin{array}{l}-0.021 \\
(0.047)\end{array}$ & $\begin{array}{c}0.062 \\
(0.067)\end{array}$ & $\begin{array}{l}-0.004 \\
(0.051)\end{array}$ & $\begin{array}{l}-0.062 \\
(0.050)\end{array}$ \\
\hline Respondent is single & $\begin{array}{l}-0.029 \\
(0.042)\end{array}$ & $\begin{array}{l}-0.010 \\
(0.060)\end{array}$ & $\begin{array}{l}-0.015 \\
(0.063)\end{array}$ & $\begin{array}{c}0.009 \\
(0.061)\end{array}$ & $\begin{array}{l}-0.069 \\
(0.060)\end{array}$ & $\begin{array}{l}-0.029 \\
(0.051)\end{array}$ & $\begin{array}{l}-0.090 \\
(0.070)\end{array}$ & $\begin{array}{l}-0.023 \\
(0.054)\end{array}$ & $\begin{array}{l}-0.021 \\
(0.055)\end{array}$ \\
\hline Respondent is divorced & $\begin{array}{c}0.006 \\
(0.044)\end{array}$ & $\begin{array}{c}0.043 \\
(0.057)\end{array}$ & $\begin{array}{l}-0.042 \\
(0.072)\end{array}$ & $\begin{array}{l}-0.011 \\
(0.062)\end{array}$ & $\begin{array}{c}0.020 \\
(0.061)\end{array}$ & $\begin{array}{c}0.017 \\
(0.051)\end{array}$ & $\begin{array}{c}0.038 \\
(0.073)\end{array}$ & $\begin{array}{c}0.084 \\
(0.058)\end{array}$ & $\begin{array}{c}0.054 \\
(0.058)\end{array}$ \\
\hline $\begin{array}{l}\text { Respondent Does not } \\
\text { have Kids }\end{array}$ & $\begin{array}{c}0.057 \\
(0.033)^{*}\end{array}$ & $\begin{array}{c}0.144 \\
(0.047)^{* * *}\end{array}$ & $\begin{array}{l}-0.032 \\
(0.050)\end{array}$ & $\begin{array}{l}-0.017 \\
(0.047)\end{array}$ & $\begin{array}{c}0.119 \\
(0.046)^{* *}\end{array}$ & $\begin{array}{c}0.059 \\
(0.039)\end{array}$ & $\begin{array}{c}0.094 \\
(0.053)^{*}\end{array}$ & $\begin{array}{c}0.055 \\
(0.043)\end{array}$ & $\begin{array}{c}0.059 \\
(0.042)\end{array}$ \\
\hline Constant & $\begin{array}{l}-0.054 \\
(0.203)\end{array}$ & $\begin{array}{c}-0.548 \\
(0.280)^{*}\end{array}$ & $\begin{array}{c}0.445 \\
(0.302)\end{array}$ & $\begin{array}{c}-0.144 \\
(0.274)\end{array}$ & $\begin{array}{c}0.270 \\
(0.313)\end{array}$ & $\begin{array}{c}0.038 \\
(0.247)\end{array}$ & $\begin{array}{c}0.358 \\
(0.367)\end{array}$ & $\begin{array}{c}-0.093 \\
(0.262)\end{array}$ & $\begin{array}{c}-0.038 \\
(0.264)\end{array}$ \\
\hline Observations & 1146 & 594 & 552 & 567 & 579 & 813 & 399 & 702 & 705 \\
\hline R-squared & 0.10 & 0.14 & 0.09 & 0.10 & 0.11 & 0.10 & 0.14 & 0.09 & 0.09 \\
\hline
\end{tabular}

Note: Robust standard errors in parentheses. Specifications also include indicators for household income. . ${ }^{* * *}, * *$ and ${ }^{*}$ respectively denote statistically different from zero at the $1 \%, 5 \%$ and $10 \%$ confidence levels. 
Table 9: OLS Estimates of the Impact of Residing in a CEIP Community on Network and Labour Market Variables

\begin{tabular}{|c|c|c|c|c|c|c|c|c|c|}
\hline & $\begin{array}{l}\text { Change in } \\
\text { number of } \\
\text { bond } \\
\text { contacts }\end{array}$ & $\begin{array}{l}\text { Change in } \\
\text { number of } \\
\text { bridge } \\
\text { contacts }\end{array}$ & $\begin{array}{l}\text { Change in } \\
\text { number of } \\
\text { links } \\
\text { contacts }\end{array}$ & $\begin{array}{l}\text { Change in } \\
\text { Number of } \\
\text { Contacts } \\
\text { Family and } \\
\text { Friends }\end{array}$ & $\begin{array}{l}\text { Change in } \\
\text { Number of } \\
\text { Contacts } \\
\text { who Help } \\
\text { with Jobs } \\
\end{array}$ & $\begin{array}{l}\text { Gross } \\
\text { hourly wage }\end{array}$ & $\begin{array}{l}\text { Usual } \\
\text { working } \\
\text { hours in the } \\
\text { job }\end{array}$ & $\begin{array}{l}\text { Holds a full } \\
\text { time job }\end{array}$ & $\begin{array}{l}\text { Holds a part } \\
\text { time job }\end{array}$ \\
\hline $\begin{array}{l}\text { Lives in a CEIP } \\
\text { community }\end{array}$ & $\begin{array}{c}1.271 \\
(1.024)\end{array}$ & $\begin{array}{c}0.744 \\
(0.207)^{* * *}\end{array}$ & $\begin{array}{c}0.040 \\
(0.019)^{*}\end{array}$ & $\begin{array}{c}0.697 \\
(0.464)\end{array}$ & $\begin{array}{c}2.030 \\
(1.067)^{*}\end{array}$ & $\begin{array}{c}0.741 \\
(0.683)\end{array}$ & $\begin{array}{l}-1.695 \\
(0.966)\end{array}$ & $\begin{array}{l}-0.013 \\
(0.018)\end{array}$ & $\begin{array}{c}-0.039 \\
(0.014)^{* *}\end{array}$ \\
\hline Age of respondent & $\begin{array}{l}-0.291 \\
(0.170)\end{array}$ & $\begin{array}{l}-0.104 \\
(0.077)\end{array}$ & $\begin{array}{c}-0.005 \\
(0.003)^{*}\end{array}$ & $\begin{array}{c}0.218 \\
(0.146) \\
\end{array}$ & $\begin{array}{l}-0.368 \\
(0.251) \\
\end{array}$ & $\begin{array}{c}0.665 \\
(0.226)^{* *}\end{array}$ & $\begin{array}{c}0.851 \\
(0.122) * * * \\
\end{array}$ & $\begin{array}{c}0.003 \\
(0.003) \\
\end{array}$ & $\begin{array}{c}0.004 \\
(0.002)^{* *}\end{array}$ \\
\hline $\begin{array}{l}\text { Age of respondent } \\
\text { squared }\end{array}$ & $\begin{array}{c}0.003 \\
(0.002)^{*}\end{array}$ & $\begin{array}{c}0.001 \\
(0.001)^{*}\end{array}$ & $\begin{array}{c}0.000 \\
(0.000)\end{array}$ & $\begin{array}{l}-0.002 \\
(0.001)\end{array}$ & $\begin{array}{c}0.004 \\
(0.002)^{*}\end{array}$ & $\begin{array}{c}-0.006 \\
(0.003) * *\end{array}$ & $\begin{array}{c}-0.010 \\
(0.001) * * *\end{array}$ & $\begin{array}{c}-0.000 \\
(0.000)^{* * *}\end{array}$ & $\begin{array}{c}-0.000 \\
(0.000)^{* *}\end{array}$ \\
\hline Respondent is Male & $\begin{array}{c}-4.067 \\
(0.726)^{* * *}\end{array}$ & $\begin{array}{l}-0.548 \\
(0.356)\end{array}$ & $\begin{array}{c}0.014 \\
(0.019)\end{array}$ & $\begin{array}{c}-1.956 \\
(0.812)^{* *}\end{array}$ & $\begin{array}{c}-4.525 \\
(1.062)^{* * *}\end{array}$ & $\begin{array}{c}4.144 \\
(0.905)^{* * *}\end{array}$ & $\begin{array}{c}8.566 \\
(0.717)^{* * *}\end{array}$ & $\begin{array}{c}0.017 \\
(0.015)\end{array}$ & $\begin{array}{c}0.058 \\
(0.009)^{* * *}\end{array}$ \\
\hline Passed high school & $\begin{array}{c}0.146 \\
(0.877)\end{array}$ & $\begin{array}{l}-0.114 \\
(0.126)\end{array}$ & $\begin{array}{c}0.011 \\
(0.017)\end{array}$ & $\begin{array}{l}-0.853 \\
(0.510)\end{array}$ & $\begin{array}{c}1.242 \\
(1.299)\end{array}$ & $\begin{array}{c}3.253 \\
(0.342)^{* * *}\end{array}$ & $\begin{array}{c}-0.301 \\
(1.063)\end{array}$ & $\begin{array}{c}0.154 \\
(0.015)^{* * *}\end{array}$ & $\begin{array}{c}0.002 \\
(0.007)\end{array}$ \\
\hline $\begin{array}{l}\text { Received a bachelor's } \\
\text { degree }\end{array}$ & $\begin{array}{c}0.698 \\
(1.067)\end{array}$ & $\begin{array}{c}0.482 \\
(0.389)\end{array}$ & $\begin{array}{c}0.030 \\
(0.027)\end{array}$ & $\begin{array}{l}-1.564 \\
(0.976)\end{array}$ & $\begin{array}{l}2.546 \\
(1.942)\end{array}$ & $\begin{array}{c}11.291 \\
(4.050)^{* *}\end{array}$ & $\begin{array}{l}-0.273 \\
(1.448)\end{array}$ & $\begin{array}{c}0.191 \\
(0.023)^{* * *}\end{array}$ & $\begin{array}{c}0.011 \\
(0.016)\end{array}$ \\
\hline $\begin{array}{l}\text { Received some } \\
\text { university education }\end{array}$ & $\begin{array}{l}-2.481 \\
(2.365) \\
\end{array}$ & $\begin{array}{c}0.262 \\
(0.506)\end{array}$ & $\begin{array}{c}0.027 \\
(0.048)\end{array}$ & $\begin{array}{c}-0.886 \\
(1.847) \\
\end{array}$ & $\begin{array}{c}0.292 \\
(2.868)\end{array}$ & $\begin{array}{c}8.803 \\
(2.371)^{* * *} \\
\end{array}$ & $\begin{array}{c}1.651 \\
(1.557)\end{array}$ & $\begin{array}{c}0.213 \\
(0.052)^{* * *} \\
\end{array}$ & $\begin{array}{c}0.024 \\
(0.027) \\
\end{array}$ \\
\hline Has 1 child & $\begin{array}{c}2.828 \\
(1.076)^{* *}\end{array}$ & $\begin{array}{c}0.323 \\
(0.499) \\
\end{array}$ & $\begin{array}{c}-0.055 \\
(0.020)^{* *}\end{array}$ & $\begin{array}{c}0.297 \\
(1.178)\end{array}$ & $\begin{array}{c}3.327 \\
(1.749)^{*} \\
\end{array}$ & $\begin{array}{l}-0.446 \\
(0.729) \\
\end{array}$ & $\begin{array}{l}-0.336 \\
(0.896) \\
\end{array}$ & $\begin{array}{c}0.038 \\
(0.018)^{*}\end{array}$ & $\begin{array}{l}-0.008 \\
(0.011) \\
\end{array}$ \\
\hline Has 2 kids & $\begin{array}{c}0.493 \\
(1.546) \\
\end{array}$ & $\begin{array}{c}0.797 \\
(0.399) * \\
\end{array}$ & $\begin{array}{l}-0.011 \\
(0.022)\end{array}$ & $\begin{array}{l}-1.334 \\
(0.993) \\
\end{array}$ & $\begin{array}{c}0.949 \\
(1.735) \\
\end{array}$ & $\begin{array}{l}-0.819 \\
(0.845) \\
\end{array}$ & $\begin{array}{l}-0.640 \\
(0.735) \\
\end{array}$ & $\begin{array}{c}0.048 \\
(0.018)^{* *} \\
\end{array}$ & $\begin{array}{l}-0.009 \\
(0.008)\end{array}$ \\
\hline $\begin{array}{l}\text { Receiving pension in } \\
\text { past } 12 \text { months }\end{array}$ & $\begin{array}{l}-1.595 \\
(1.227) \\
\end{array}$ & $\begin{array}{c}-1.708 \\
(0.444)^{* * *}\end{array}$ & $\begin{array}{l}-0.014 \\
(0.035)\end{array}$ & $\begin{array}{l}-0.057 \\
(0.956) \\
\end{array}$ & $\begin{array}{c}-3.149 \\
(1.667)^{*}\end{array}$ & $\begin{array}{c}2.602 \\
(3.831) \\
\end{array}$ & $\begin{array}{c}-4.214 \\
(0.957)^{* * *}\end{array}$ & $\begin{array}{c}-0.333 \\
(0.021)^{* * *}\end{array}$ & $\begin{array}{c}-0.042 \\
(0.011)^{* * *}\end{array}$ \\
\hline $\begin{array}{l}\text { Receiving EI/SA in past } \\
12 \text { months }\end{array}$ & $\begin{array}{l}-0.152 \\
(0.807)\end{array}$ & $\begin{array}{l}-0.058 \\
(0.216)\end{array}$ & $\begin{array}{l}-0.012 \\
(0.013)\end{array}$ & $\begin{array}{c}0.675 \\
(0.579)\end{array}$ & $\begin{array}{l}-0.476 \\
(1.261)\end{array}$ & $\begin{array}{c}-1.393 \\
(0.456)^{* * *}\end{array}$ & $\begin{array}{c}1.337 \\
(0.930)\end{array}$ & $\begin{array}{c}-0.137 \\
(0.020)^{* * *}\end{array}$ & $\begin{array}{c}-0.033 \\
(0.011)^{* * *}\end{array}$ \\
\hline Constant & $\begin{array}{c}3.252 \\
(5.260) \\
\end{array}$ & $\begin{array}{c}0.910 \\
(1.798)\end{array}$ & $\begin{array}{c}0.230 \\
(0.057)^{* * *}\end{array}$ & $\begin{array}{c}-5.472 \\
(3.794) \\
\end{array}$ & $\begin{array}{c}2.404 \\
(6.794) \\
\end{array}$ & $\begin{array}{l}-5.148 \\
(4.604) \\
\end{array}$ & $\begin{array}{c}20.443 \\
(3.097)^{* * *}\end{array}$ & $\begin{array}{c}0.628 \\
(0.087)^{* * *}\end{array}$ & $\begin{array}{c}-0.025 \\
(0.052) \\
\end{array}$ \\
\hline Observations & 3198 & 3268 & 4304 & 3508 & 2949 & 1496 & 2537 & 4304 & 4304 \\
\hline R-squared & 0.01 & 0.01 & 0.01 & 0.01 & 0.01 & 0.06 & 0.13 & 0.34 & 0.04 \\
\hline
\end{tabular}

Note: Robust standard errors clustered at the community level in the parentheses. Specifications also include indicators for family type, indicators if the

respondent has 3 kids or 4 kids or more. . ${ }^{* * *}, * *$ and * respectively denote statistically different from zero at the $1 \%, 5 \%$ and $10 \%$ confidence levels. 